\title{
Heziketa Fisikoko bi irakasleren jardueraren azterketa: jakintza-arloaren eta hizkuntzaren arteko artikulazioaren aztarnak ${ }^{1}$
}

David Fernández Jiménez Agurtzane Azpeitia Eizagirre

Mondragon Unibertsitatea

DOI: $10.1387 / \tan t a k .17480$

GAKO-HITZAK: ekintzaren azterketa, autokonfrontazioa, ekintza tipikoak, tipifikazioak.

\section{SARRERA}

Eskola-testuinguruaren baitan, azken urteotan, aldarrikatu izan da irakasleak egiten duen jardueraren azterketa eta prestakuntza-inguramendu berrien beharra, bai Ekintzaren Bilakaera korrontetik (Cours d'action) (Theureau, 1992), bai Jardueraren Klinika korrontetik (Clinique de l'activité) (Clot, Faïta, Fernandez, \& Scheller, 2000), eta baita Formazio Gogoetatsuaren ikuspegitik ere (Esteve \& Alsina, 2010). Ildo bertsuan ari dira lanean didaktika espezifikoetatik; hala nola, artikulu honetan fokutzat jotzen diren hizkuntzaren didaktikatik (Bronckart, 2007; Plazaola Giger \& Ruiz Bikandi, 2012) nahiz heziketa fisikoaren didaktikatik (Gal-Petitfaux \& Durand, 2001).

Azken ildo horretatik, garrantzitsutzat jotzen da Heziketa Fisikoko irakasleen jarduera erdigunera ekarri eta aztertzea, eta bere ezaugarriak, hutsuneak, indarguneak eta, oro har, dauden joerak azaleratzea. Izan ere, Heziketa Fisikoko irakasleen egiteko moduan oraindik ere aktibismorako ${ }^{2}$

${ }^{1}$ Lan hau MINECO (EDU2012-37889) laguntzari esker egin da.

2 Aktibismorako joera hori honako aipuak ongi islatzen du: «Las sesiones son un simple hacer, una sucesión de actividades motrices, sin momentos ni oportunidades en que favorecer y fomentar el aprendizaje y la reflexión del alumnado sobre lo que se hace. $\mathrm{Ni}$ momentos de presentación o explicación de lo que se va a trabajar» (López Pastor et al., 2005:13). 
zein errekreazionismorako ${ }^{3}$ joera nabarmentzen dela adierazten dute hainbat adituk (Barbero González, 2005; García Monge, 2005; Bores Calle, 2005; López Pastor et al., 2005; Del Valle \& De la Vega, 2007); hau da, heziketa fisikoko saioak, oro har, ongi pasatzera eta aktibitateak modu jarraituan gauzatzera mugatzen direla, egiten dutenaren gaineko hausnarketarik eragin gabe. Irizpide didaktiko eta pedagogikoari begira, beharrezkotzat jotzen da hausnartzeko, eztabaidatzeko eta, oro har, ikaslearen jokabide motor jakinari zentzua emateko berbalizazio-ekintzak ere bultzatzea. Horrelako ekintzek ikasleak zein irakasleak oztopoak eta hobetzekoak identifikatzera eramango lituzkete; azken batean, jokabide motorra hobeto ulertu, ezagutu eta garatu baitaiteke hizkuntzarekin artikulatzen bada. Horrek berarekin dakar irakasleek ohiko irizpide anatomiko-fisiologikoei baino garrantzi handiagoa ematea irizpide pedagogiko-didaktikoei (Bores Calle, 2005).

Beraz, funtsezkoa da Heziketa Fisikoko bi irakaslek gelan egiten duten ekintza aztertzea eta jarduera horretan egon dauden heziketa fisikoaren eta hizkuntzaren arteko aztarnak azaleratzea . Horrek eskatzen du giza jardueran fokua jartzen duten marko teoriko kontzeptual eta metodologietan oin hartzera.

\subsection{Jardueraren azterketa}

Ikerketa-lan hau, teorikoki, ekintzaren edo giza jardueraren ereduetan oinarritzen da, eta horietatik, lan honetarako nabarmendu nahi dira Schützen (1972) ekintza sozialaren teoria eta elkarrekintza soziodiskurtsiboaren oinarri enuntziatiboak (Bronckart 2007).

Irakaskuntza giza jarduera den heinean, irakasleen lana ulertzeko beharrezkoa da egileak (irakasleak) bere jarduera eta ekintza hori nola ulertzen duen sakon aztertzea. Izan ere, Schützi (2007) jarraituz, esanahia eta zentzua egileak berak ematen dio, ez kanpoko behaketa soilak. Horretarako, egilea bere esperientzietan oinarritzen da, baina bere esperientzia hori ez da norbanakoarena bakarrik, sozialki eraikia baizik. Horregatik, egileak ekintza-egoerak tipoetan atzematen ditu: ekintza tipikoetan. Ekintza tipikoak, bada, lan egiteko moduak dira, sozialki eraikita eta kulturalki antolatuta daudenak; beraz, prozesu luze baten ondoren (gurasoengandik nahiz irakasleengandik jasotako heziketa, eskolako lan- kulturatik eta erakundeetako lan egiteko moduetatik jasotakoa...) ohiko bihurtzen dira egilea-

\footnotetext{
${ }^{3}$ La extensión del discurso de la importancia de lo lúdico en el aprendizaje ha sido malinterpretado en el área de EF [Educación Física] y llevado al extremo, de forma que ha acabado generando un tipo de enfoques y sesiones de EF en que lo único que parece importar es que el alumnado se lo pase bien, sin importar si ha habido aprendizajes de algún tipo o no (López Pastor et al., 2005:13).
} 
rentzat. Azken batean, sozialki eraikitako ekintza tipikoen erregulartasunek kolektiboaren tipikalitatea osatzen dute, eta egileak horietara jo dezake ekintza gauzatzerakoan. Tipikalitatea gauzatu eta birmolda dezake egileak tipifikazioari edo ekintzaren ezaugarritzeari esker (Cefaï, 1994). Izan ere, ezaugarritze horiek erabat lotuta daude testuinguruari; beraz, ez dago «tipoa» orokorrean, baizik eta arazo praktiko bati loturiko tipo indexatu batzuk (Ozaeta, 2013).

Heziketa fisikoko jardueraren azterketan oinarritutako ikerketa batzuek (Gal-Petitfaux \& Durand, 2001) kokatutako ekintza ${ }^{4}$ (testuinguruari lotutakoa) hartu dute oinarri. Ikuspegi horretatik, Suchmanek (Béguin \& Clot, 2004:37an aipatua) aipatzen duen bezala, ekintza errealaren zati garrantzitsu bat ez da plangintzaren betetze soila, ekintza bera ezin baita banandu gauzatzen den egoera edo testuinguru zehatzetik; beraz, ulertzen da ekintzak eta egoerak elkarri eragiten diotela eta uneoro nahiz ekintzaren bilakaeran elkar definitzen dutela (Gal-Petitfaux \& Durand, 2001; Saury, Ria, Sève \& Gal-Petitfaux, 2006). Horrez gain, alderdi emozionalak ere zuzeneko eragina du lan errealean (Ria, Sève, Saury, Thereau, \& Durand, 2003; Pradas \& Lopez Ros, 2010).

Era berean, ekintzaren azterketari begira azaltzen da «ergonomia» terminoa, ingeniariaren(?), lan filosofiaren(?) eta psikologiaren apustu diziplinartekoa; interesgarria da mundu frankofonoan izandako garapena, ezagutza hori irakaskuntzan aplikatu baita (Plazaola Giger, 2006). Frantses ergonomia kognitiboak analizatzen du jarduerarekiko giza ekintzak duen erlazioa; horren baitan, ekarpen garrantzitsua izan da agerian uztea preskribatutako lanaren eta lan errealaren arteko aldea (Montmollin, 1986). Hau da, beharrezkoa da ekintza erreala analizatzea, beti ez baitator bat gelako jarduera erreala eta aldez aurretik prestatutako eta preskribatutako lana (Plazaola Giger, 2007b; Bronckart, 2007).

\subsection{Autokonfrontazioa, ekintza aztertzeko tresna metodologikoa}

Lan erreala aztertzeko, autokonfrontazio-metodoa edo ekintzaren aurrez aurreko elkarrizketa erabiliko da ikerketa-tresnatzat, jarduera horren aztarnak azaleratzeko ez ezik, egileak egin duen jarduera berbalizatuz zentzua emateko aukera aproposa ere sortzen duelako.

Ekintzaren bilakaera korrontetik ${ }^{5}$ (Theureau, 1992, 2005) bakarkako autokonfrontazioa aldarrikatzen da egilearen esperientzia ahalik eta zehatzena jasotzeko metodotzat. Ikertzailea bidelagun izanik, egilea bere lanaren bideoaren aurrean jarri eta egindako lana aztertzea du helburu metodo

\footnotetext{
4 «Situated action» kontzeptua itzultzeko erabili dugu.

5 «Cours d'action» kontzeptua itzultzeko erabili dugu.
} 
horrek. Jarduera klinikoaren ${ }^{6}$ baitan (Clot, et al., 2000), autokonfrontazio metodoa erabiltzen da egilearen gogoeta baimentzeko. Metodo horrekin, irakasleak ekintza gauzatu duen une eta egoerara itzuli eta birbizitzeko aukera izango du, dituen indargune nahiz oztopoak identifikatu eta, batez ere, beste balizko egiteko modu batzuk aurkitzeko (Clot, et al., 2000). Autore honek uste du ekintzaren aurrez aurreko azterketan oinarrituta, helburuak, bitartekoak, lanaren ezagutza eta bere transformazioa langileak berak egin ditzakeela.

Autokonfrontazio-metodo edo ikerketa-tresna hori Hizkuntza-irakasleen jarduera aztertzeko ez ezik, Heziketa Fisikoko irakasleena aztertzeko ere erabili izan da. Heziketa Fisikoan, irakaslearen eta ikasleen arteko komunikazio eta interakzioetan, erregulazio- ekintza tipikoak azaleratu dira (Gal-Petitfaux \& Saury, 2002). Horrez gain, atzeman da irakaslearen eta ikaslearen arteko sozializazio-prozesu interaktiboetan sortzen dela esanahien eraikuntza, eta eraikuntza prozesu horretan negoziazioek oinarrizko papera dutela (Gal-Petitfaux \& Vors, 2008). Horrek aztergai den heziketa fisikoaren eta hizkuntzaren arteko artikulazioan sakontzeko aztarna batzuk erakusten ditu.

\subsection{Heziketa fisikoaren eta hizkuntzaren arteko artikulazioa}

Heziketa fisikoaren didaktikatik (Larraz, 2008; Vaca Escribano, 2008; LLeixà, 2007) aldarrikatzen da Heziketa Fisikoak oinarrizko gaitasunak lantzeko aukera paregabea eskaintzen duela eta Hezkuntza-legearen curriculumetan ere (Oinarrizko Curriculum Diseinua eta Euskal Curriculuma) alderdi hori azpimarratzen da. Pertsonaren garapen integrala ez da mugimendu hutsarekin lortzen. Praxiologia Motorraren ikuspegiak aldarrikatzen duen bezala, funtsezkoa da «jokabide motorra» lantzea (Parlebas, 2008); hau da, ekintza hori ikasleek zentzuz eta intentzio jakin batekin egiten ikasteko bitartekoak eskaintzea (Larraz, 2008). Bitarteko nagusia (ahozko) hizkuntza bera da, ahozko hizkuntzak motrizitatean erregulazio-funtzioa egiten baitu eta jarduera fisiko kolektiboetan sortzen diren negoziazio-prozesuetarako ere funtsezkoa baita (LLeixà, 2007). Izan ere, hitz egitea, entzutea eta elkarrizketatzea ohiko jarduerak dira Heziketa Fisikoan (Vaca Escribano, 2008).

Are gehiago, heziketa fisikoko saioetan gaitasun linguistikoak berariaz eta nahita lantzeko egoera natural eta aproposak sortzen dira. Ohikoak dira, esate baterako, ahoz zein idatziz egiten diren jardueren edo bizipenen inguruko azalpenak, deskribapenak, debateak eta gogoetak (Larraz, 2008). Azken batean, ahozko zein idatzizko testu-generoak ${ }^{7}$ erabili eta lantzeko au-

\footnotetext{
6 «Clinique de l'activité» kontzeptua itzultzeko erabili dugu.

7 «Es a través de los géneros que las prácticas de lenguaje se encarnan en las actividades de los alumnos» (Dolz \& Schneuwly, 1997:29).
} 
kera eskaintzen du. Aldi berean, jakintza-arloetan sakontasun eta arrakasta handiagoa lortuko da, baldin eta hizkuntzari ere erreparatzen bazaio. Jakintza-arlo bakoitzak, izan ere, bere berariazko hizkuntza du, bere hiztegi propioa du (Coelho, 2004). Jaubert-ek eta Rébiere-k dioten bezala, hizkuntza eta jakintza-arloa banaezinak dira: «[...] eskolako ezagutzak (jakintzak) eraikitzeko, ezinbestekoa da, beste hainbat gauzaren artean, diziplina bakoitzaren berariazko hizkuntzaren ahozko eta idatzizko gaitasunak garatzea.» (Sainz Osinaga, Azpeitia, Garro, \& Sagasta 2011:17an aipatzen den bezala).

Horrenbestez, lan honetan heziketa fisikoaren eta hizkuntzaren arteko artikulazioarekin bete-betean egiten zaio erreferentzia diziplinartekotasunerako aukerari . Hori gauzatzerakoan datoz, ordea, zailtasunak. Nola lortu biak modu orekatu eta artikulatu batean lantzea? Gerta liteke, eta gertatu ohi da adituen ustez (Bores Calle, 2005; Barbero Gonzalez, 2005), irizpide anatomiko-fisiologikoak edo ludikotasuna gailentzea irizpide pedagogikoen aurretik, eta aktibismoak eragindako $\operatorname{arazoak}^{8}$ azaleratzea; hitzezko komunikazioa murriztu, eta ondorioz, pentsamenduaren, elkarrizketaren eta kontzientzia hartzearen galera azaleratzen dira. Hau da, hitzezko komunikazioa soilik ikasleak motibatzeko edo zuzentzeko adierazpenetara mugatu daiteke:

A este respecto, hace ya cierto tiempo que distintos autores (i.e. Hargreaves, 1986) han puesto de manifiesto el predominio de un lenguaje escueto, telegráfico, casi reducido al uso de imperativos, expresiones de ánimo o rechazo y exclamaciones, que a veces se sustituyen o complementan con otra gama de sonidos (palmadas, silbidos, etc.). Una forma de comunicación bajo la que subyace un código muy restringido y contextualizado que margina otras formas de comunicación más densas y articuladas porque reducen el tiempo de la práctica (Barbero González, 2005:102)

Izan ere, arriskua dago pentsatzeko ekintzaren gaineko gogoetak eta, oro har, ikaskuntza kontzientea gelan sustatzeak saioaren aprobetxamendua $^{9}$ gutxitzen duela, hizkuntzaren erabilera eta lanketa jokabide motorraren kontzientzia hartzearekin batera bigarren plano batean aurkitzen baita.

${ }^{8}$ Hiru ohiko modu: 1. Hizkuntzaren erabilera, gogoeta eta pentsamendua alde batera uzten dutenak. 2. Teoria praktikatik banantzen dutenak. 3. Saioaren aprobetxamendua jardueren kantitatearen arabera neurtzen dutenak (Barbero Gonzalez, 2005).

${ }^{9}$ Saioaren aprobetxamendua (tiempo útil) neurtzeko erabili ohi da jardueren kantitatea edo horietan lortzen den praktikaren aprobetxamendua. Saioaren aprobetxamendutik kanpo gelditzen dira beste honako alderdi garrantzitsu hauek: ikasleari hasieran ematen zaion informazioa, atazen hasierako informazioa, gelaren kudeaketa, materialak prestatzea eta jasotzea, debateak, galderak, balorazioak... (Barbero Gonzalez, 2005). 
Beraz, lan honetan interesatzen zaigu ikustea Heziketa Fisikoko bi irakasle horien lanean, heziketa fisikoaren eta (ahozko) hizkuntzaren arteko artikulaziorik ba dagoen, eta balego, zeintzuk diren horren aztarnak.

\section{ALDERDI METODOLOGIKOAK}

\subsection{Helburuak}

Lan honen helburu nagusia da Heziketa Fisikoko bi irakasleren lana eta egiteko modua aztertzea. Horretarako, honako hiru helburu zehatz azpimarratzen dira: a) egilea (Heziketa Fisikoko bi irakasleak) bere jarduerari aurrez aurre jartzen zaionean eta egiten duen hori berbaldira ekartzen duenean, zein ekintza tipiko egiten dituen aztertu eta ekintza tipiko horietan egon dauden erregulartasunak azaleratzea b) ekintza horiek irakasleek nola tipifikatzen edo ezaugarritzen dituzten aztertzea; hau da, beren jarduera nola iruzkindu, azaldu, definitu, adibidetzen duten aztertzea c) jarduera horietan heziketa fisikoaren eta hizkuntzaren arteko artikulaziorik gauzatzen ote den eta, hala balitz, nola gauzatzen den aztertzea.

\subsection{Corpusa}

Ikerketa-corpusa Gipuzkoako Ikastola bateko bi irakaslek egiten duten saio banak eta saio horien gaineko autokonfrontazioek osatzen dute ${ }^{10}$. Irakasle horiek tutore nahiz Heziketa Fisikoko irakasle dira ikastetxe horre$\tan$

Irakasle horietako batek (IRAK1 bezala izendatuko dugu hemendik aurrera) 10 urteko ibilbidea du eskola-kiroleko begirale gisa, baina azkeneko zortzi urteetan hezkuntzan lan egiten dihardu; horietatik lau ikasturte daramatza (2005-2006; 2008-2009; 2009-2010 eta 2013-2014 ikasturteetan) tutore izateaz gain, Heziketa Fisikoko irakasle-lanetan. Aztergai den irakasle horren saioa LH3 eta LH4. mailako ikasleak elkarrekin daudela grabatu da (zikloko planteamendua egiten da) eta bertako ikaste-objektua akrosport-a izan da ${ }^{11}$. Ikasgelan guztira 23 ikasle dira (12 neska eta

${ }^{10}$ Saio horiek ez ziren saio isolatuak, sekuentzia didaktikoaren barnean zeudenak baizik. Hori dela eta, saioa bere osotasunean ulertzeko planifikazio-lanak (irakasleek prestatutakoa) eta saioen grabazioak ere kontuan izan ditugu, baina ez ditugu aztergai izan. Badakigu dokumentu eta grabazio horien berariazko azterketa egitea ere, interesgarria litzatekeela ekintzen errealitatera gehiago gerturatzeko, horrek planifikatutako lanaren eta lan errealaren arteko harremanean sakontzea dakarrelako, baina hori hurrengo lanetarako utzi dugu.

${ }^{11}$ Koreografia akrobatikoak. 
11 mutil); horietatik 17 haurrek dute lehen hizkuntzatzat gaztelania eta $6 \mathrm{k}$ euskara eta gaztelania. Bigarren irakasleak (IRAK2 bezala izendatuko da lan honetan) zortzi urtez lan egin zuen eskola kiroleko begirale gisa eta azkeneko bederatzi urteetan hezkuntzan dihardu. Horietatik azken 6 urteetan ikastola honetan aritu da tutore eta Heziketa Fisikoko irakasle lanetan. Aztergai den irakasle horren saioa 6. mailan grabatu da eta ikaste-objektutzat saskibaloia izan du. Ikasgelan, guztira 27 ikasle dira (14 neska eta 13 mutil); horietatik 17 haurrek dute lehen hizkuntzatzat gaztelania eta 10ek euskara eta gaztelania.

Laburbilduz, corpus-bilketak honako ezaugarriak (1 Taula) ditu:

1. taula

Corpusaren ezaugarriak

\begin{tabular}{|c|c|c|}
\hline Ezaugarriak & IRAK1 & IRAK2 \\
\hline $\begin{array}{l}\text { Ikaste-objektua } \\
\text { Saioaren iraupena } \\
\text { Grabaketa-data } \\
\text { Maila }\end{array}$ & $\begin{array}{l}\text { Akrosport-a } \\
\text { Denbora: } 2 \text { ordu } \\
\text { Data: } 2014-03-26 \\
\text { Maila: 3. eta } 4 \text {. LH (zi- } \\
\text { kloko planteamendua) }\end{array}$ & $\begin{array}{l}\text { Saskibaloia } \\
\text { Denbora: } 2 \text { ordu } \\
\text { Data: } 2014-03-21 \\
\text { Maila: } 6 . \text { LH }\end{array}$ \\
\hline $\begin{array}{l}\text { Ikaste-objektuaren auto- } \\
\text { konfrontazioa } \\
\text { Iraupena } \\
\text { Grabaketa-data }\end{array}$ & $\begin{array}{l}\text { Bai. } \\
\text { Denbora: 88:13 } \\
\text { Data: 2014-03-28 }\end{array}$ & $\begin{array}{l}\text { Bai } \\
\text { Denbora: } 47: 15 \\
\text { Data: } 2014-03-24\end{array}$ \\
\hline \multirow[t]{2}{*}{$\begin{array}{l}\text { Transkribapenaren iriz- } \\
\text { pideak }\end{array}$} & \multicolumn{2}{|c|}{ 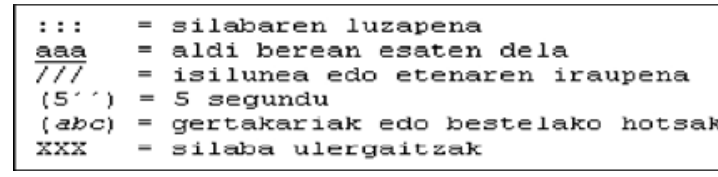 } \\
\hline & \multicolumn{2}{|c|}{ MIKER taldean adostutakoak } \\
\hline $\begin{array}{l}\text { Transkribapena egiteko } \\
\text { baliabideak }\end{array}$ & Transana (softwarea) & Transana (softwarea) \\
\hline
\end{tabular}

\subsection{Corpusa jasotzeko prozedura}

Atal honetan analisirako datuak jasotzeko erabilitako prozedura zehatza azalduko da, bai egiturari dagokionez, bai alderdi metodologikoei dagokienez .

Lehenik, aztertutako bi irakasleen saioak grabatu dira; saio horiek sekuentzia didaktiko bakoitzaren parte dira. Saioa, eguna eta ordua irakas- 
leek aukeratu dituzte. Ondoren, saio horiekin bakarkako autokonfrontazioak egin dira. Beraz, 2 fase desberdintzen dira:

\section{1. fasea. Saioen grabazioa}

Saioak ikertzaileak berak grabatu ditu eta irakaslearen hitzari eta ekintzari jarraitzeko kirol kantxatik jarraitu zaio. Irizpidea izan da saioa ez oztopatzea, baina baita irakaslearen eta ikasleen arteko elkarrekintza ahalik eta ondoen jarraitzea ere.

Bestetik, irakasleei ez zaie konsigna zehatzik eman, ez saioaren aldez aurretiko prestakuntzari dagokionez, ez eta gelako kudeaketari eta elkarrekintzari dagokienez ere. Bakar-bakarrik eskatu zaie ahalik eta modurik naturalenean jokatzeko, nahiz eta grabatuak izan.

\section{2. fasea. Bakarkako autokonfrontazioak}

Autokonfrontazio-elkarrizketak saioa grabatu eta bizpahiru egunetara egin dira. Pradasi (2010) jarraituz, ikerketa gehienek diote komeni dela saioaren grabazio- mementotik elkarrizketara pasatzen den denbora ahalik eta txikiena izatea. Garbi dago memoria iheskorra dela eta, irakasleek grabatutako saioa aldez aurretik ikusi ez dutenez gero, berbalizatzeko arazoak ekar ditzakeela denbora-tarte luzeegiak. Izan ere, irakasleei ez zaie eskatu grabaketa aurrez ikusteko, horrela autokonfrontazioan saioa grabatu zen unea berriz bizi eta birdeskubritzeko aukera handiagoa dagoelako; hau da, hizketa eragilea ${ }^{12}$ bultzatzea izan da helburua (Merleau Ponty , Richir-ek aipatua 1988).

Aurrez aipatutako alderdi metodologikoak oinarri hartuta (Theureau, 2005; Clot et al., 2000) egin dira autokonfrontazioak. Oinarri horien arabera, autokonfrontazio- metodoari esker, irakaslea aurrez aurreko irudien eta ikertzailearen ondoan jarri eta berbaldira ekarriko du zein ekintza gauzatu dituen, zergatik, zein helbururekin, zein baldintzatzaile izan dituen...; hau da, saioan gauzatzen dituen ekintzen analisia egingo du bideoaren eta ikertzailearen aurrean. Horrek eramango du ekintza gauzatu zuen une eta leku horretara, eta bertan egindako guztia birbizitzera. Beraz, ez da ohiko elkarrizketa bat, eta hori azpimarratu zaie irakasleei autokonfrontazioaren hasierako konsignan:

Hau izango da elkarrizketa bat bion eta bideoaren artean, hiruron artean. Bertan, zuk zure jarduera ikusteko aukera daukazu. Nahi duzun to-

\footnotetext{
12 «Parole opérante» edo hizketa eragilea: aurrez ez dakien zerbait edo inoiz esan ez duen zerbait hitzetara ekartzeko egileak erabiltzen duen hizketa-moldeari deritzo. Esan gabekoa esateko bilaketa horretan, diskurtsoa birformulatu, zehaztu, osatu, xehetu eta, oro har, eraldatu egiten du, harik eta esan duenaren eta esan nahiko zukeenaren artean alderik txikiena egon dadin (Merleau Ponty, Richir-ek aipatua 1988).
} 
kian geldi dezakezu, komentarioak egin, ea zer ikusten duzun, zer uste duzun, zeintzuk diren zure kezkak, zalantzak, indarguneak eta hobetzeko alderdiak. Ni nago zuri laguntzeko eta bidelagun ${ }^{13}$ izateko prozesu hone$\tan$.

\subsection{Analisirako tresnak eta irizpideak}

Egindako ekintzari zentzua emateko egileak egiten duen berbalizazioan, hots, autokonfrontazioan, ekintza tipikoak identifikatu eta tipifikazioak $^{14}$ aztertzeko egileek erabiltzen dituzten ekintza-enuntziatuetan jarri da arreta. Bertan bi plano diskurtsibo hartu dira kontuan (Plazaola Giger \& Friedrich, 2005; Plazaola Giger, 2007a): plano topikala (tematizatzen den ekintza oro) eta plano iruzkintzailea. Horrez gain, elkarrizketa batzuetan atzeraeraginezko mugimenduak azaldu dira, non egileak aurretik egindako ekintza diskurtsora ekartzen duen. Beraz, zeintzuk dira azterketaren analisi-unitateak?

\section{Ekintza-enuntziatuak aztertzeko irizpideak}

1. Plano topikala: egileak jarduera identifikatu eta aztertzean, diskurtsora ekartzen dituen ekintzen sarea edo konstelazioa da. Tipikalitatearen berri ematea du helburu.

2. Plano iruzkintzailean, berriz, plano topikalean azaleratu duen ekintzaren enuntziazioa bera aztertuko da: nola ezaugarritu duen, nola modalizatu ${ }^{15}$ nahiz definitu eta birformulatu duen, egilea nondik hitz egiten ari den (agentibitatea), egon litezkeen baldintzatzaileak edo aldarteak nola azaldu dituen... Azterketa honetan, bereziki, azkeneko biei eman zaie garrantzia: jarduera-inguramenduaren aldarteen enuntziazioari eta agentibitatearen diskurtso-markei.

Jarduera-inguramenduaren aldarteak jotzen ditugu irakasleek ekintza gauzatzeko dituzten baldintzatzat. Bertan, desberdindu ditugu kanpo-baldintzatzaileak (materiala, espazioa, denbora...) eta barne-baldintzatzaileak (gaitasunak, egilearen errekurtsoak, jarduerarekiko ardura eta irakaslearen

${ }^{13}$ Ikertzaileen helburua ez da izan irakasleak egiten duena edo egiten ez duena ebaluatzea. Helburua da irakaslea zertan ari den ulertzea, zer nahi ote duen, zer esan nahi ote digun. Ikertzaileek hartzen duten jarrerak ere baldintza dezake autokonfrontazioa. Autokonfrontazioaren helburua da irakasleak gelan egin duena deskribatu, aztertu eta interpretatzea; hau da, intentzioak, barne-bizipenak, motiboak azaleratzea.

14 Tipifikazioa diogunean, bigarren mailako tipifikazioa dugu buruan, jarduera- unearen ondorengoa baita.

15 Modalizazioak egileek jardueraz duten jarrera edo posizioa ematen du aditzera, ahalmena, desioa, behar izanak... zehazten ditu. 
eduki mental eta emozionalak: intentzioa, motibazioa, asmoak, kezkak...) jardueran eragina duten alderdiak ikusteko (Bronckart, 2007).

Horiekin batera, agentibitatearen diskurtso-markak ere aztergai izango dira (Bronckarten 2007). Adierazle horiek egileak nondik hitz egiten duen jakiteko aztarnak ematen dituzte; hau da, ekintza kolektiboa ala indibiduala den eta ekintzarekiko hartzen duen jarrera (modalizazioa) zein den ikusteko aztarnak.

\section{ANALISIA}

\subsection{Plano topikala: egileek autokonfrontazioetan identifikatutako jarduera eta ekintzak ${ }^{16}$}

Egileek (IRAK1 eta IRAK2) beren saioetan akrosport-a eta saskibaloia landu dituzte. Akrosport-a lantzeko, irakasleak (IRAK1) diskurtsora ekartzen dituen jarduerak honako hauek dira: 1) aurrezagutzak aktibatzea, 2) saioa kokatzea, 3) martxan jartzea, 4) taldeka forma akrobatikoak egitea, 5) lasaitasunera bueltatzea.

Bestetik, saskibaloia landu duen irakasleak (IRAK2) diskurtsora ekartzen dituen jarduerak honakoak dira: 1) saioa kokatzea, 2) martxan jartzea, 3) paseak eta jaurtiketak lantzea, 4) partidu zabala jokatzea, 5) saioaren hausnarketa eginaraztea, 6) lasaitasunera bueltatzea.

$\mathrm{Bi}$ autokonfrontazioetan azaleratzen da irizpide fisiologiko-anatomikoetan oinarrituriko egitura tipikoa: 1) berotzea, 2) atal nagusia edo saioaren gai nagusia garatzen den unea (hau da, IRAK1en 4. jarduera eta IRAK2ren 3. eta 4. jarduerak) eta 3) lasaitasunera bueltatzea. Baina, horrez gain, aurretik, saio bakoitza kokatu ere egiten dute, irizpide pedagogiko didaktikoei erantzunez. Gainera, IRAK1en kasuan, sekuentziari hasiera eman behar dionez eta ikasleentzat gaia ezezaguna denez, aurrezagutzak aktibatzeko jarduera egiten du. Jarduera ${ }^{17}$ bakoitza gauzatzeko, askotariko ekintzak egiten dituzte.

16 Jarduera eta ekintza horiek izendatzeko, irizpide gisa hautatu dugu egileak autokonfrontazioan erabilitako hitzetatik ahalik eta hurbilen dagoen izendapena, oinarri teorikoetan genion bezala, egileak berak ematen diolako zentzua ekintzari (Schütz, 2007).

17 «Jarduera», Leontievi (1984) jarraituz, xede bati orientatuta dagoen prozesu intentzionatu eta egituratua da eta «ekintzak» ditu osagai nagusi; hots, ekintzen bidez operatibizatzen da. 


\subsubsection{Aipatzen dituzten jarduera eta ekintza tipikoak irakasleka}

\begin{tabular}{|c|c|}
\hline IRAK1 (Akrosport saioa) & IRAK2 (Saskibaloia saioa) \\
\hline \multicolumn{2}{|l|}{ Aurrezagutzak aktibatzea } \\
\hline \multicolumn{2}{|l|}{$\begin{array}{l}\text { a) Ekintza tipikoa: ikasleak hausnartu, } \\
\text { pentsarazi eta ideia desberdinak } \\
\text { bota ditzan eragin. }\end{array}$} \\
\hline \multicolumn{2}{|l|}{$\begin{array}{l}\text { b) Ekintza tipikoa: ideiak partekatu eta } \\
\text { ikasleen arteko interakzioa bideratu } \\
\text { (galderak eginaz). }\end{array}$} \\
\hline c) Ekintza tipikoa: adibidetu. & \\
\hline Saioa kokatzea & Saioa kokatzea \\
\hline $\begin{array}{l}\text { d) Ekintza tipikoa: biribilean eserarazi } \\
\text { eta azalpenak eman. }\end{array}$ & $\begin{array}{l}\text { E) Ekintza tipikoa: biribilean eserarazi } \\
\text { eta azalpenak eman. }\end{array}$ \\
\hline Martxan jartzea (Beroketa) & Martxan jartzea (Beroketa) \\
\hline $\begin{array}{l}\text { h) Ekintza tipikoa: harrapaketa joko- } \\
\text { jolasean irakasleak mezu zuzenak } \\
\text { eman. }\end{array}$ & $\begin{array}{l}\text { e) Ekintza tipikoa: korrika eta luzake- } \\
\text { tak eginarazi. } \\
\text { f) Ekintza tipikoa: jolasa azaltzeko } \\
\text { azalpen motzak eman. } \\
\text { g) Ekintza tipikoa: gogoeta edo haus- } \\
\text { narketa eragin. }\end{array}$ \\
\hline $\begin{array}{l}\text { Taldeka forma akrobatikoak egitea } \\
\text { (Atal nagusia) }\end{array}$ & $\begin{array}{l}\text { Paseak eta jaurtiketak lantzea } \\
\text { (Atal nagusia) }\end{array}$ \\
\hline \multirow{5}{*}{$\begin{array}{l}\text { i) Ekintza tipikoa: kantxaren erdian } \\
\text { elkartu azalpena emateko. } \\
\text { j) Ekintza tipikoa: taldekatzeen ingu- } \\
\text { ruko hausnarketa eragin. } \\
\text { k) Ekintza tipikoa: ikasleek azpitalde- } \\
\text { tan landu dutena ikusi. }\end{array}$} & $\begin{array}{l}\text { 1) Ekintza tipikoa: azalpena eredu gisa } \\
\text { eman. }\end{array}$ \\
\hline & Partidu zabala (Atal nagusia) \\
\hline & $\begin{array}{l}\text { m) Ekintza tipikoa: denon parte-har- } \\
\text { tzea ziurtatzeko partidua antolatu. }\end{array}$ \\
\hline & Saioaren hausnarketa eginaraztea \\
\hline & $\begin{array}{l}\text { n) Ekintza tipikoa: ikasleen inpresioa } \\
\text { jaso. }\end{array}$ \\
\hline $\begin{array}{l}\text { Lasaitasunera bueltatzeko joko bat } \\
\text { egitea }\end{array}$ & $\begin{array}{l}\text { Lasaitasunera bueltatzeko joko bat } \\
\text { egitea }\end{array}$ \\
\hline $\begin{array}{l}\text { Ekintza tipikoa: atzamarretako giha- } \\
\text { rrak landu. }\end{array}$ & $\begin{array}{l}\text { p) Ekintza tipikoa: jaurtiketa libre txa- } \\
\text { pelketa antolatu. }\end{array}$ \\
\hline
\end{tabular}




\subsection{Plano iruzkintzailea}

Goian aipaturiko jarduera eta ekintza horiei egileek zentzua nola ematen dieten (eta beraz, nola tipifikatzen dituzten) aztertzeko egileen enuntziazioei erreparatuko diegu. Horrekin batera, ordea, funtsezkoa da jarduera bakoitzean agertzen diren jakintza-arloaren eta hizkuntzaren arteko aztarnak zein diren azaltzea. Horrela, artikuluaren bigarren eta hirugarren helburuei ere helduko zaie.

Plano topikalean ikusi da saioek egitura komuna dutela, baina zeintzuk dira gauzatutako sekuentzien eta saioen intentzio eta helburuak?

\begin{tabular}{|c|c|}
\hline IRAK1 & IRAK2 \\
\hline $\begin{array}{l}\text { (4) IRAK1: bueno gai berri batekin has- } \\
\text { ten gara / akrosporteko gaia izango da / } \\
\text { eurentzat berria da berez / ezdaue emon } \\
\text { gai hori eta bueno pentsatu dogu onena } \\
\text { berez sekuentzia hiru saiotan itxia/ lehe- } \\
\text { nengo egunian eukiko deuena izango da } \\
\text { lehenengo kontaktu bat / ezagutza bat } \\
\text { akrosportakin eta / bigarrena izango da } \\
\text { ya eurek aurkezpen bat prestatzia eta hi- } \\
\text { rugarren saiua ya izango da aurkezpen } \\
\text { hori aurkeztia guztion aurrian / zeintzuk } \\
\text { izango dien guk planteatzen ditugun } \\
\text { helburuak? Ba izango die alde batetik } \\
\text { lehen esan bezela akrosporta ezagutzia } \\
\text { eta horrekin batera bat: trebezia lantzia } \\
\text { eta bestetik talde lana bultzatzia / / or- } \\
\text { duen horrek die batez be eukiko ditxu- } \\
\text { gun helburuak }\end{array}$ & $\begin{array}{l}\text { (4)IRAK2: Bueno ba saio hau da / sas- } \\
\text { kibaloiko saio bat seigarren mailan gra- } \\
\text { bautakua eta da saskibaloiko hirugarren } \\
\text { saioa/ sekuentzia didaktikoko hiruga- } \\
\text { rren saiua/ Aste Santua gertu dauzenez } \\
\text { ba segun fetxekin lau edo bost saioko } \\
\text { sekuentzia didaktiko bat izango da (...) } \\
\text { eta saskibaloiaren helburu nagusia da } \\
\text { ba saskibaloia pixkat gehixao ezagutzea } \\
\text { eta beste modu baten saskibaloiaz goza- } \\
\text { tzea/ eta saio honen konkretuki helburua } \\
\text { ba: saskibaloiaz gozatzea / pixkat be pa- } \\
\text { seak lantzea / saskibaloiko paseak eta: } \\
\text { eta gero jolas bat ezagutzea gero be- } \\
\text { raiek pixkat kalean jolasteko lagunekin } \\
\text { ikastolatik kanpo jolastorduetan edo / } \\
\text { eta: beti bezela ba saskibaloiaz goza- } \\
\text { tzia / eta sekuentzia hau dago sartuta bi- } \\
\text { garren hiruilabetian / eta bigarren hirui- } \\
\text { labetian landu ditugu kirolak / taldeko } \\
\text { kirolak / landu genuen eskubaloia, bo- } \\
\text { leibola eta hau hirugarrena izango zan } \\
\text { saskibaloia. }\end{array}$ \\
\hline
\end{tabular}

Bi irakasleek aztergai duten saioa sekuentziaren barnean kokatzen dute. Beraz, garbi dago ez garela saio isolatuez ari: IRAK1en kasuan, hiru saioko sekuentzia da «sekuentzia hiru saiotan itxia», eta IRAK2ren kasuan lau edo bost saiotara luza litekeena: «Aste Santua gertu dauzenez ba segun fetxekin lau edo bost saioko sekuentzia didaktiko bat izango da». 
IRAK1engan aipagarria da diskurtsoan darabilen «pentsatu dugu» horrek aditzera ematen duen agentibitate-marka; izan ere, badirudi, saioak ez dituela bakarka prestatzen edo ikastetxe horretako egiteko modu kolektiboari egiten diola erreferentzia. Hau da, lehen pertsona pluralaren atzean ez dago irakasle-ikasleak biltzen dituen multzoa, irakasleak (Heziketa Fisikoko irakasleak, agian) biltzen dituena baizik: «eurentzat berria da berez / ezdaue emon gai hori eta bueno pentsatu dogu...». IRAK2k darabilen lehen pertsona pluralaren atzean («eta bigarren hiruilabetian landu ditugu kirolak / taldeko kirolak / landu genuen eskubaloia, boleibola...»), aldiz, ikasleak eta irakaslea biltzen dituen taldea legoke.

IRAK1ek sekuentziaren helburutzat jotzen ditu akrosport kirolarekin kontaktua egitea, aurkezpena prestatzea eta aurkeztea. Horrela ikusita, bada, helburu komunikatibo bat azaltzen da, hizkuntzaren didaktikarekin lotura nabarmena duena. Autokonfrontazioan aurrera doala, ordea, akrosport-a ezagutzea, trebezia lantzea eta talde-lanean aritzea duela helburu azpimarratzen du. Beraz, ikusten da autokonfrontazioan barna, helburuak zehazten eta xehatzen ari dela.

IRAK2rentzat sekuentziaren xedea saskibaloia ezagutu eta «gozatzea» da. Gozatzeari garrantzi handia ematen dio, bere diskurtso laburrean hiru alditan azpimarratzen baitu («beste modu baten saskibaloiaz gozatzea», «eta saio honen konkretuki helburua ba: saskibaloiaz gozatzea», «eta: beti bezela ba saskibaloiaz gozatzia«, eta gainera, ohiko xedetzat jotzen du. Horrek «errekreazionismorako» joera badagoela pentsaraztera garamatza, nahiz eta, analisian ikusiko den bezala, ikasleak hausnartzera bultzatzen dituen.

Behin saioen helburu eta asmoak zehaztuta, egileek jarduerei eta ekintzei zentzua nola ematen dieten aztertuko da.

\subsubsection{Jarduera: aurrezagutzak aktibatzea}

a) EKINTZA TIPIKOA: IKASLEAK HAUSNARTU, PENTSARAZI ETA IDEIA DESBERDINAK BOTA DITZAN ERAGIN

\section{IRAK1}

(10)IRAK1: bueno hemen ikusten douena apur bat da / garrantzia haundixa ematen zauena / da beti / gai bat hasterakuan / izan heziketa fisikokua edo beste edozein gai hasterakuan beti interesatzen jakuna da ezagutzia euren aurrezagutzak / orduan hori bultzatzen dou / lehenengo eurek hausnartzia / pentsatzia / ideia ezberdinak botatia eta hortik hasten gara / ba benetan zein puntutan aurkitzen diren eurek gai horretan ikusteko

Aurrezagutzak abian jartzea edozein diziplinatan ohikoa den jarduera gisa azaltzen du irakasleak: «garrantzia haundixa ematen zauena da / beti 
gai bat hasterakuan / izan heziketa fisikokua edo beste edozein gai hasterakuan». Hau da, ez du berak soilik egiten duen ekintzatzat jotzen; agentibitateari dagokionez, «Gu» batetik ari da hitz egiten: «ikusten douena», «interesatzen jakuna, bultzatzen dou, hasten gara». «Gu» edo «Gara» lehen pertsona plurala erabiliz, kolektiboaren tipikalitatea osatzen duen jarduera gisa azaltzen du eta ikastetxe horretako kolektiboaren printzipio pedagogikoei edo eduki mentalari egiten dio erreferentzia: «bultzatzen dou lehenengo eurek hausnartzia, pentsatzia / ideia ezberdinak botatzia».

Garbi dago IRAK1 ez dela berak egin duen ekintza horretara bakarrik mugatzen, Heziketa Fisikoan ez ezik, gainerako jakintza-arloetan ere egiten dituztelako. Ekintzari zentzua ematerakoan, bada, bestek egindako ekintzak ekartzen ditu, baina baita berak beste une batzuetan egin ohi dituenak ere (ekintza-sare bat). Jokabide horrek Schützen ekintza erreala ulertzeko moduarekin bat egiten du:

El significado de mi acción no consiste sólo en las vivencias de conciencia que tengo mientras la acción está en curso, sino también en aquellas vivencias futuras que constituyen la acción a que tiendo, y en aquellas pasadas que constituyen mi acción completada (Schütz, 1972:69).

b) EKINTZA TIPIKOA: IDEIAK PARTEKATU ETA IKASLEEN ARTEKO INTERAKZIOA BIDERATU (GALDERAK EGINEZ)

\section{IRAK1}

(12) I: Abiatzen zerate pixkat ikasleen aurrezagutzetatik edo beraiek duten egoera ezagutzarekiko

IRAK1: Hori da / hori da / hor ikusten da ba dana oso ezberdina dala / ba batek identifikatzen zauen bezela akrosporta ya zerbaitekin lotzen auen / figurak egitia etabar / baina beste batzuk daz eurendako lehenengo aldixa dala akrospor hitza entzuten dabiena eta hutsetik hasten die / orduan ba bueno / hor ezberdintasunak daz eta lortzen doguena da ba euren arteko interakziño horrekin edo / ba bueno / guztiek maila berdineraz bideratzia.

(21-26)I: Galdera horiek nola planteatzen dituzu edo zer galdera zehatz dira:?

IRAK1: Ez / batez be galderak kasu gehienetan ez ditugu prestatuta eramaten / zertarako? Ba azkenian eurek botatako:/ hasiera batean ideia orokor bat botatzen jako / galdera orokor bat botatzen jako eta eurek emandako erantzuna kontutan izanik bideratzen dugu hausnarketa alde batetik edo bestetik / galdera zehatzak eramaten baditugu euren erantzuna beti izango da zuk indako galderai / aldiz zabala einda ba bueno bide ezberdinetatik bideratu laike

I: Galdera irekiak / uhu

IRAK1: Gero orduen eztaz zehaztuta / da momentuan irtetan dauena edo euren interesak dien arabera $(\ldots)$ 
Aurrezagutzak aktibatzeko bigarren ekintza bat ere egiten du: ikasleek ideiak parteka ditzaten eragin eta irakasle-ikasleen zein ikasleen arteko solaskidetza («euren arteko interakziño horrekin») bideratu. Ikus liteke, beraz, bi elkarrekintza mota horiek sustatu nahi dituela eta horretarako galderak, nahiz eta aldez aurretik prestatu gabe ekarri («galderak kasu gehienetan ez ditugu prestatuta eramaten»), badituela elkarrekintza sustatzeko irizpide pedagogiko kolektibo batzuk: galdera «orokor, zabal» edo irekiak egiten saiatzen da, galdera zehatzek ikasleen erantzunak baldintzatu eta irakasleak entzun nahi duen horretara mugatzea ekartzen dutelako eta irekiek, aldiz, ikasleen interesak azaleratzea baimentzen dutelako. Elkarrekintza mota horiekin ikasleek dituzten aurrezagutza askotarikoak kontuan izan eta guztiek oinarrizko abiapuntua behintzat izan dezaten bermatu nahi du: «hor ezberdintasunak daz eta lortzen doguena da ba euren arteko interakziño horrekin edo / ba bueno / guztiek maila berdineraz bideratzia». Esan bezala, ekintza hori enuntziatzeko «Gutik» hitz egiten du eta izan bada ikastetxeko kolektiboaren ekintza tipiko bat. Eta hori «gu» eta «euren» izenordeekin azpimarratu egiten da: «Guk» (irakasleok) lortzen dugu «euren» (ikasleen) arteko interakzioarekin guztiak maila berera bideratzea.

c) EKINTZA TIPIKOA: ADIBIDETU

IRAK1

(16)IRAK1:[...] hemen ikusi dugun bezela / ba bueno / adibide bat jartzen tzau eurei apur bat euren aurrezagutzetan laguntza emateko ez? ba irudi bidez askotan aberatsagoa da edo gehio ikasten daue/ ordun ba bueno emotentzau lehenengo adibidetxo bat / ba bueno / euren aurrezagutzetan (...)

Ikasleen aurrezagutzak ateratzen laguntzeko, hirugarren ekintza bat ere jartzen du abian; irakasleak irudi bidezko adibide bat eskaintzen du (eredu bat) arrazoi jakin batekin: «irudi bidez askotan aberatsagoa da edo gehio ikasten daue». Ekintza horrek ere irakasle- kolektiboaren egiteko moduei egiten die erreferentzia: «jartzen tzau» edo «emoten tzau», eta goian gertatzen zen bezala, «gu» eta «eurak» izenordainekin indartzen du. Hortaz, tipikalitatea osatzen duen beste ekintza baten aurrean geundeke.

Aurrezagutzak aktibatzeko jarduera hori hizkuntzaren eta arloaren arteko artikulazioa egiteko agerleku aproposa da; izan ere, ahozko hizkuntza erabiltzen du ikasleekin batera, irakaskuntza-elkarrekintza dialogikoan (Esteve, 2009) ezagutza eraikitzeko bitarteko gisa, eta bereziki askotariko ikuspegiak azaldu eta defendatzeko bitarteko gisa. 


\subsubsection{Jarduera: saioa kokatzea}

\section{d) EKINTZA TIPIKOA: BIRIBILEANESERARAZI ETA AZALPENAK EMAN}

\begin{tabular}{l}
\hline \multicolumn{1}{c}{ IRAK1 } \\
\hline (42-44) IRAK1: Orduan ba bueno \\
hemen berez gelako edo aurrezagutzen \\
saiua edo momentua bukatzen da eta ya \\
praktikara pasatzen gara (..) \\
IRAK1: Beste espazio bat da / espa- \\
zio zabal bat / zailtasun gehixao azalpe- \\
nak ematerako orduan / horregatik esan \\
dut ba igual zala momentu egokixena \\
helburuak adierazteko
\end{tabular}

(49-54)I: Uhu / (...) espazioaren baldintzak ez? hor erabaki zenun ohiko gelan egitea aurrezagutzena eta hemen / klaro esaten duzu azalpenak egiteko igual zailtasun gehiago daudela?

(50-54)IRAK1:(...) eta: zailtasunak egoten die / esaterakuan / espazio zabal bat ikusten daue eurek eta espazio zabalean ya edozein mezu ematea zailagoa da / edo guztiak ixilik edo entzun edo arreta jartzeko eskatzia zaiaoa izaten da / orduan garrantzitsua da ohitxura batzuk hartzia edo ya hasiera hasieratik eurekin pauta batzuk adostia / hori al dan neurrixan errexago izateko. (...)

IRAK1: Orduan eurek adibidez badakixe bertan ezarritako lehenengo kontua dala eurek kantxara heltzen dienian eta eurek gauzak itxi ostian zelai erdian kokatuko direla / orduan hor eseriko die eta hor ya emangotzau mezu orokorra / eta ya lehenengo ariketa azaldukotzau (...) eurekin ezarritako puntu bat da/ bestela helduko zien kantxara eta hasiko die korrika alde guztitatik

I: momentu hau da ezta?

IRAK1: Bai // beti mezua emoteko borobil erdi bat itxen saiatzen gara inorri bizkarra ez emateko baina bueno askotan ikusten dan bezela ba oso zaial itxen jakie borobil erdi bat sortzia
IRAK2

(10-14)IRAK2: hemen ikusten da itxoiten dutela pixkat eurak borobila in arte / ze hor seguruenik ez da ikusten baina baterenbat borobil barruan edo egongo zan / eta daukot esanda ba oso garrantzitsua dala hasieratik pixkat danok aurpegia ikustia / bai azalpenetan bai jolas bat azaltzerako orduan eta ba orduan borobilean jartzen gara beti / eta bueno badakizu orduan ba hamar segundu hoiek itxoitzen seguruenik norbait lekuz kanpo edo baloiren bat jasotzen edo egongo zala (...)

I: Aha / espazioa antolatzen duzu hitz egiteko / eta momentu hori? Eta hor zer bideratzen duzu? Zein da helburua momentu horretan?

IRAK2: Momentu horretan da pixkat gogoratu aurreko saioan zer ein gauen eta azaldu saio honetan zer landuko duten edo nola joango dan saioa gutxigorabehera/// ordurarte izan da pixkat gogoratu aurreko astian zer in gauen

I: Bai bai/ ikasleak kokatzeko ezta?

IRAK2: Hori da eta hoin pixkat ya azalpena hurrengo saioana / gaurko saioana (5:26-6:47 irakasleak saioa azaltzen die ikasleei eta lehenengo ariketa egiten hasten dira)/ ba holan saio gehixenak holan asten dire/ gogoratu eta gero kokatu apur bat ikasleak eta zer ingo dogun egun horretan 
Saioa kokatzea da Heziketa Fisikoko bi irakasleek konpartitzen duten lehendabiziko jarduera tipikoa. Horretarako, «borobilean eserita jolasa azaltzeko ekintza aipatzen dute».

IRAK1ek jarduera-inguramenduaren aldarteak ekartzen ditu diskurtsora, kanpo- baldintzatzaileak; izan ere, espazio zabalean (kiroldegiko kantxan kasu honetan) «arreta jartzeko eskatzia zailagoa izaten da». Eta zailtasun hori ezaugarritzen du birformulatuz eta zailtasunak zertan datzan gehiago zehaztuz: «espazio zabalean ya edozein mezu ematea zailagoa da / edo guztiak ixilik edo entzun edo arreta jartzeko eskatzia zailaoa izaten da».

Hau da, behin oztopoa identifikatuta duela, bera gainditzeko proposamena egiten du; horretarako, jabetza batetik abiatzen da: «garrantzitsua da ohitxura batzuk hartzia edo ya hasiera hasieratik eurekin pauta batzuk adostia». Mezua ongi ulertarazteko funtsezkoa den ohitura hori zein den zehaztu egiten du: 1) zelai erdian kokatu, 2) zelai erdian eseri eta 3) mezua ongi emateko, biribil erdia osatu, horrela inori ez diotelako bizkarrik emango. Horrek, azken batean, jarduerarekiko duen ardura, intentzioa... aditzera ematen du; hots, barne- baldintzatzaileak ekartzen ditu.

IRAK2k ere espazio zabalean azalpenak emateko jardueran, «pauta» edo «ohitura» gisa ekartzen du diskurtsora barne- baldintzatzailea: «daukot esanda ba oso garrantzitsua dala hasieratik pixkat danok aurpegia ikustia».

Bai batak (IRAK1), bai besteak (IRAK2) espazioaren zabalerak sor ditzakeen komunikazio-oztopoak (kanpo-baldintzatzailea) gainditzeko, ikasleak modu bertsuan kokatzen dituzte; bada, beraz, ikastetxe horretako Heziketa Fisikoko irakasleen ohiko ekintzaren eta tipikalitatearen osagai: «borobilean jartzen gara beti» eta «saio gehixenak holan die». Eta horren adierazgarri dira «saio gehixenak», nahiz «beti» aditzondoak.

Bai IRAK1ek , bai IRAK2k tipifikatzerakoan zehaztu egiten dute ematen duten mezua zein den: «emangotzau mezu orokorra / eta ya lehenengo ariketa azaldukotzau». Hau da, mezu orokorra eman, ariketa azaldu, jolas bat azaldu... Beraz, egin beharreko ekintzaren kontsignak erabateko garrantzia hartzen du bi irakasleen jokabidean, baina ez horrek bakarrik: IRAK2rentzat komunikazio-une hori funtsezkoa da memoria didaktikoa egiteko; hau da, «momentu horretan da pixkat gogoratu aurreko saioan zer ein gauen eta azaldu saio honetan zer landuko duten». Agentibitateari dagokionez, IRAK1ek modu inpertsonalean kokatzen du saioa «garrantzitsua da»; IRAK2k, ordea, diskurtsora ekartzen du bere ekintza gisa: «daukot esanda garrantzitsua dala».

Saioa kokatzeko jarduera eta ekintza horietan ere hizkuntzaren eta arloaren arteko artikulaziorako aukerak ikusi dira; izan ere, saioa jarraitzeko instrukzioak ageri dira. Hau da, biribilean esertzen dira azalpenak entzuteko, saioan zer landuko den azaltzeko eta lehenengo ariketaren azalpena egiteko. Beraz, instrukzioaren generoa dago bete-betean eta bertan egin beharrekoaren konsignak eta jolas-arauen testu-moldeak azaltzen dira. Ekintzen deskribapena eta jokabideen erregulazio konpartitua lantzeko 
aproposa den jarduera eta ekintza tipikoa da. Beraz, ikasleek instrukzioak eta jolas-arauak jasotzeko zein azaltzeko aukera ematen duen unea da.

\subsubsection{Jarduera: martxan jartzea}

e) EKINTZA TIPIKOA: KORRIKA ETA LUZAKETAK EGINARAZI

IRAK2

(19)IRAK2: Hemen dabitz / beti itxen dogu bost minutu korrika gutxi gorabehera eta da / gehixenbat atzaldien die saiuak bebai eta hasieran ez zabien itxen ezer / ba hasi eta ya harrapaketa jolas bat edo zerbait / eta gero askok tripako mina, barea eta ba bost minutu pixkat honen aldetik ez dabe itxen / ba pixkat gorputza martxan jartzen daue eta gero harrapaketan edo zerbait ya martxan jartzerako orduan askoz hobeto/ eta korrika in eta gero beti beste borobil baten elkartzen gara eta beraietako batek / (...) egun horretako arduradunak zerrendan arabera (...) luzatu itxen dau / lehenengoko urteko lehenengoko lau bost saioetan nik luzatzen dot / pixkat azaltzen dotziet nola luzatu, zergatik / eta gero ya urte guztiko luzaketak eurek eramaten dabe (...) badakite saskibaloia lantzen gabitzela eta saskibaloia lantzeko ba ze luzatu bikoda? Ta kasu honetan berak esan zaban / besoak / ba ondo / lau bost luzaketa besoetan / eta gero hankak eta gero beste helburua da ya giharren izenak eta ba ikasten joatia ta nola luzatu gihar hoiek

Martxan jartzea da bi autokonfrontazioetan azaltzen den beste jarduera tipiko bat, beroketa helburu duten ekintzak lantzen dira bertan. Hala ere, jarduera hau planteatzeko, bi irakasleek ekintza tipiko desberdinak planteatzen dituzte. IRAK1ek harrapaketa joko-jolasak ${ }^{18}$ eta IRAK2k, berriz, korrika egitea eta luzaketak egitea aipatzen du ekintza tipiko gisa. Ekintza horiek «gutik» ekartzen ditu diskurtsora «beti itxen dogu», «beti beste borobil batean elkartzen gara», eta ohikotasunaren adierazle, «beti» aditzondoa erabiltzen du; beraz, ekintza ohiko eta kolektibo gisa azaltzen ditu. Hala ere, kasu honetan, badirudi irakasle- eta ikasle-taldeari buruz ari dela eta ez irakaslekolektiboari buruz, kontrakotasuna azpimarratzen baitu lehen ikasleek egiten zutenaren eta orain, irakaslea barne, egiten dutenaren artean: «hasieran ez zebien (ikasleek) itxen ezer (...) hasi eta gero askok tripako mina; orain, beti itxen dugu bost minutu korrika» (...), «luzatu itxen dau».

Bi ekintza bezala ulertzen baditugu ere, ekintza tipiko horiek oso lotuta daude eta multzo berean sartzen ditu irakasleak diskurtsoan: «korrika in eta gero beti beste borobil baten elkartzen gara eta beraietako batek / (...) egun horretako arduradunak zerrendan arabera (...) luzatu itxen dau». Ekintza tipiko horiek tipifikatzean, ekintzen inguruan dituen eduki mental

${ }^{18}$ H ekintza tipikoa izenburupean sakonduko dugu. 
eta emozionalak ekartzen ditu diskurtsora; korrika egitearen atzean dagoen intentzioa azaleratzen du, eskarmentuak eragin baitio bere egiteko moduan aldaketak egitea; hau da, ikasleen baldintzek «tripako mina» saioaren ekintza tipikoa aldatzera eraman dute, beraz, harrapaketaren aurretik txertatzen duen ekintza tipiko gisa azaltzen du.

Horrez gain, luzaketak egitearen ekintza tipikoa tipifikatzen edo ezaugarritzen du: «lehenengoko urteko lehenengoko lau bost saioetan nik luzatzen dot / pixkat azaltzen dotziet nola luzatu, zergatik / eta gero ya urte guztiko luzaketak eurek eramaten dabe». Beraz, ikasleen autonomia sustatu nahi da eta bere diskurtsoaren bidez ere aditzera ekartzen du. Nabarmena da, bada, lehen pertsona singularretik («ni» batetik) hirugarren pertsonara («eurak» batera) egiten duen jauzia: 1. pertsona: «nik, dot», -----1. pertsonaren eta3.aren arteko lotura «azaltzen dotziet», eta azkenik, 3. pertsona «eurak eramaten dabe».

Jarduera-inguramenduaren aldarteak ikus daitezke pasarte honetan; ekintza hori ikasturte osoan zehar egiten du, irakaslearen barne-baldintzatzailea edo errekurtsoa baita modu progresiboan ikasleei ekintzaren protagonismoa ematea. Gainera, ikasleek ekintza gidatzeaz gain, badu beste helburu bat ere, hizkuntzari loturiko helburua, hain zuzen: «beste helburua da ya giharren izenak eta ba ikasten joatia ta nola luzatu gihar hoiek». Beraz, hizkuntza espezifikoa lantzeko erabiltzen den urte osoko ekintza gisa ekartzen du diskurtsora, jakintza-arloaren berariazko hizkuntza lantzea du helburu, bere hiztegi propioarekin (Coelho, 2004; Sainz Osinaga et al., 2011).

\section{f) EKINTZA TIPIKOA: JOLASA AZALTZEKO AZALPEN MOTZAK EMAN}

\section{IRAK2}

(31-36) I: Eta hor azalpenak egiten dituzu ezta?

IRAK2: Bai / hemen azalduko dot zer dan hurrengo jolasa/ bueno hau ezaguna zan beraientzat orduan (...)

I: Aha/ kontutan hartzen duzu:

IRAK2: Bai ba igual formatu berdin berdinak ez baina holako tipologia ariketak antzerakoak izaten dia beti /ta orduan paseen jolasak beti dira berdinak / ba baloia ezin da lurrera jauzi: baloia daukanai ezin zaio ikutu edo inguratu / baloia daukona ezin da mugitu / eta eurok badakixe hori bosgarren mailatik (...) noizian behin zerbait aldatzen da baina oso ezaguna da beraientzat /// ikusten da / azalpena oso motza da ezta:/ hori pertsona batek ez duena ezagutzen ez du ulertzen zer jolastu biadaue (...) ezta azaldu ez eremuak / espaziua nola antolatu bidauen / hiru talde bai / bost pase eta ya ezta / orduan segun jolasa ezaguna dan edo ez dan azalpenak modu batera itxen dituzu edo bestera (...)

(42) IRAK1: bai ezbazan ezaguna izango: azalpena oso txarra da (...)

IRAK2k ikasleei jolasa zertan datzan azaltzeko, «azalpen oso motza» ematen duela dio; baina azalpena motza izatearen arrazoiak azalera- 
tzen ditu: ikasleek eta irakasleak jolasa ezaguna dute eta, beraz, batean duten informazio pragmatikoak, hitzez hitz azalpena bere osotasunean eman gabe ere, elkar ulertzea dakar: «hau ezaguna zan beraientzat (...) eta eurok badakixe hori bosgarren mailatik». Horrez gain, jolasaren formatua edo generoa ezaguna izateak, hitzez hitz esan gabe ere inferitzeko aukera handia eskaintzen die ikasleei: «holako tipologia ariketak antzerakoak izaten dira beti». Pasekako jolas orok bete beharreko instrukzio-arauak ekartzen ditu ariketa-tipo hau hobeto ezaugarritzeko, eta horretarako instrukziozko testuetan ohikoa den «aginteraz» baliatzen da: «baloia ezin da lurrera jauzi, baloia daukanai ezin zaio ukitu edo hau ezin da inguratu, baloia daukona ezin da mugitu». Beraz, ikasleek duten informazio guztia ez dator irakasleak memento horretan egiten duen azalpen motzetik, eta hori agentibitatearen arrastoek ere azaleratzen dute: «ni» batetik abiatzen du tipifikazioa («azalduko dut»), baina ondoren, modu inpertsonalean sakontzen du («tipologia ariketak antzerakoak izaten dia beti).

Irakasleak garbi du, bada, azalpenak ikasleen ezagutza mailara egokitu behar dituela: «orduan segun jolasa ezaguna dan edo ez dan azalpenak modu batera itxen dituzu edo bestera» (...) «ezbazan ezaguna izango: azalpena oso txarra da (...).

Honenbestez, autokonfrontazioan irakasleak aukera du bere ekintzaren arrazoiak, argudioaketa baldintzatzaileak azaleratzeko, eta horrek egindakoari zentzua ematen dio.

\section{g) EKINTZA TIPIKOA: GOGOETA EDO HAUSNARKETA ERAGIN}

\section{IRAK2}

(58-62)IRAK2: eta askotan hori / jartzen ditxut berriro hemen esan dutena:/ ez:/ pentsatzera (...) honekin zer lortu duzue? Zerbait lortu duzue? Noiz lortzen dozue bost pase? Noiz ez dozue lortzen? Zer gertatzen da? eta: pixkat bideratzen dituzu eta segituan ateratzen dozu zuk nahi duzun informazioa

I: Hau zer da ariketa bukatutakoan edo noiz egiten duzu?

IRAK2: Ez hau uste dot zala ariketa erdian / uste dot espazioa ezaben oso ondo antolatzen / asko pilatzen ziren baloiaren inguruan eta nik nahi nuan reflexio bat itxia / jolasa moztu nauen / uste dot / ez dakit / ez nao oso ziur baina uste dot jolasa moztu nauela eta beraiekin hitz egin nauela

I: Bai bai baietz uste dut/ ta zein zan honen helburua? (...)

IRAK2: Pixkat espazioa hobeto antolatzia / ez pilatzea baloiaren inguruan ta konturatzia espazioa sakabanatzen dozunian eta pixkat areriotik urruntzen dazenian bost pase lotzia oso errexa dala (...)// ya atera daue nik nahi nauan informaziua ez? orduan esaten dotzet egoera bat lotzeko / hau esan dot / noiz gertatu da? han / ah ba bai 
Pasarte horietan ikus daiteke IRAK2k egiten duen ohiko ekintza dela ikasleek hausnar eta pentsa dezaten eragitea: «eta askotan hori jartzen ditxut berriro hemen esan dutena: /ez:/ pentsatzera». Izan ere, «askotan» aditzondoak ohikotasuna aditzera ematen du, baina badirudi bere egiteko moduan dela ohikoa; izan ere, agentibitateari dagokionez, ez du «gu» batetik hitz egiten, kasu honetan, «ni» batetik hitz egiten du. Horrez gain, «reflexioa bat itxia» ekintza tipifikatzen du ikasleek oso ondo egiten ez duten ekintza bat zuzentzeko erabiltzen duela, errekurtso gisa: «espazioa ezaben oso ondo antolatzen / asko pilatzen ziren baloiaren inguruan eta nik nahi nuan reflexio bat itxia / jolasa moztu nauen». Beraz, inguramenduaren aldarteak ekartzen ditu diskurtsora. Kasu honetan, gogoeta egitea barne-baldintzatzailea planteatzen du kanpo-baldintzatzailearen baldintzak (espazioa) zuzentzeko. Erregulazio-ekintza horrek bat egiten du Gal-Petitfaux eta Sauryk (2002) aipatzen duten erregulazio-ekintza tipikoarekin ; «arrêt» edo gelditzea ekintzarekin bat egiten du. Kasu honetan, ekintza indibiduala izan beharrean kolektiboa da, baina xede berarekin: ekintza gelditzen da arazoaren arrazoiak argitzearren.

\section{h) EKINTZA TIPIKOA: HARRAPAKETA JOKO-JOLASEAN IRAKASLEAK MEZU ZUZENAK EMAN}

\section{IRAK1}

(60-70)IRAK1: bai// askotan be ba bueno / apur bat gu bebai kontraesanetan sartzen gara / ikusten dan bezela askotan esaten dou / garrantzitsuena da umiei askotan ixtea libre eurek erabakitzeko / eurek bilatzeko soluzinuak edo bihar dana / eta askotan / ba hori / ikusten dan bezela gure mezuak die zuzenean bideratuta / eta askotan emanbiajakie mezu zuzenak / holan ta holan izan behar dala / orduan ba bueno askotan hortan jausten gara

I: Eta zer iruditzen zaizu:?

IRAK1: Ez ba bueno nik askotan esaten dotena / teoria oso politxa da baina askotan ba horretan jausten gara eurei pentsatzen utzi biharrian gu ya zuzenean erantzuna ematen tzau eta bideratu itxen ditxugu

I: zuzentzaileak edo garela?

IRAK1: Hori da eh: arauak edo biadana ya zuzen zuzenian emotentzau baina bueno / hola suertatzen da eta esan dotena eh: teorian bai eta teoria danok dakigu azkenian baina praktikarako orduan ba:

I: Saiatzen zera hori aurrera eramaten? bueno

IRAK1: Bai baina momentuan urtetzen jatzun zerbait da orduan ba ba

I: Hor ikusi dozu / bideoan ikusi dozu? 


\section{IRAK1 (jarraitu)}

IRAK1: Hori da zu joaten zara igual prest / esaten bueno gaur itxi bitziet apurtxo bat eurek hausnartzeko eurek pentsatzeko edo: baina bueno / gero heltzen da momentua eta askotan pum bideratu itxen dituzu zuzenian zer inbidabien

I: Eta hor zer egin ahal zenuen edo hori aldatzeko? edo egin duzun hori beste era batera edo nahi duzun edo irudikatzen duzun teoria hori aurrera eramateko?

IRAK1: ez eske horretara noia azkenean oso zaia izaten dalako eurek bilatzea / ezbotzazu emoten azkenian arauak zehatz zehatz / bakoitza hasten bada araua bere aldetik ikusten edo / ba bueno izan laike saio dana / bueno jolas dana oztopatzia ez? eta suertatzia ba jolas bat kaos bat izatia / orduan ba bueno / momentu honetan ezdauket hola erantzun zuzen bat/ saiatu? Ba bai saiatzen zara baina zaia da

Pasarte horietan ikus daiteke irakaslearen intentzionalitatea eta ezina, irakaslearen eduki mental eta emozionalak. Eta horren baitan, ekintzaren inguramenduaren aldarteak, barne-baldintzatzaileak, irakaslearen gaitasunak eta errekurtsoak.

Lehenik, ekintza tipiko eta kolektibo moduan ekartzen du diskurtsora: «askotan be ba bueno / apur bat gu bebai kontraesanetan sartzen gara». «Gu» horren atzean badirudi irakasle-kolektiboa dagoela, kasu honetan, Heziketa Fisikoko irakasleak. Gainera, adierazgarria da ohikotasuna adierazteko ekintza tipifikatzean, bederatzi aldiz ekartzen duela diskurtsora «askotan» aditzondoa.

Pasarte horretan ikus liteke teoriaren eta praktikaren arteko jauzia, irakasleak bizi dituen kontraesanak: «garrantzitsuena da umiei askotan ixtea libre eurek erabakitzeko / eurek bilatzeko soluzinuak». Hala ere, mezu zuzenak ematen dituela konturatzen da «askotan esaten dotena / teoria oso politxa da baina askotan ba horretan jausten gara eurei pentsatzen utzi biharrian gu ya zuzenean erantzuna ematen tzau eta bideratu itxen ditxugu». Hemen ikusten da, beste lan batzuetan bezala, preskribatutako lanaren eta lan errealaren arteko aldea (Plazaola Giger, 2007b; Bronckart, 2007). Hau da, irakaslearen eduki mental eta emozionalak azaltzen dira: intentzioa (ikasleei pentsatzen uztea), balorazioa (mezu zuzenak ematen dituela konturatzean), desioak (teoria abian jartzea), jabetzak (askotan eman behar zaizkiela mezu zuzenak) eta kezkak (teoria praktikara nola eraman eta kaos egoeren ondorioz saioa eskutik joatea).

Azken batean, beraz, harrapaketa joko-jolasean mezu zuzenak ematen dituela dio. Gal-Petitfaux eta Sauryk (2002) aipatzen duten «flash» ekintzaren parekoa da; izan ere, «suivi» edo jarraipena egiten die ikasleei memento horretan, ondoren, ikasleengana gerturatzeko eta jokabide kolekti- 
boak zuzentzeko. Alde horretatik, IRAK2ren eta IRAK1en artean badago aldea. IRAK2k bere saioetan zehar galderak eginez ikasleak hausnartzera eraman nahi ditu; IRAK1ek ere bai, baina hori buruan izan arren, askotan, praktikan zuzenean zer egin behar duten azaltzen die: «Hori da zu joaten zara igual prest / esaten bueno gaur itxi bitziet apurtxo bat eurek hausnartzeko eurek pentsatzeko edo: baina bueno / gero heltzen da momentua eta askotan pum bideratu itxen dituzu zuzenian zer inbidabien».

Martxan jartzea jarduera tipiko honetan ere azaleratu dira hizkuntza eta arloa artikulatzeko abaguneak. Esan bezala, IRAK2k luzaketak egitean hiztegi espezifikoa lantzen duela adierazten du: « [...] helburua da giharren izenak eta ba ikasten joatia ta nola luzatu gihar hoiek». Beraz, Heziketa Fisikoan hizkuntza berariaz lantzeko jarduera eta ekintza tipiko bat da. Ekintza horretan, hizkuntzaren lanketa hiztegi espezifikoa ikastetik harago joateko, posible litzateke ikasleek ahoz azaltzea luzatzeko mugimenduen instrukzioak.

Horrez gain, martxan jartzea jarduera berean hausnarketa edo gogoeta egiten du IRAK2k espazioan kokatzeko zailtasunak gainditzeko helburuarekin. Ekintza tipiko honek ere ekintzen deskribapena baimendu dezake, eta horren baitan, bizipenaren azalpena edo kontaketaren lanketa.

\subsubsection{Jarduera: taldeka forma akrobatikoak egitea}

i) EKINTZA TIPIKOA: KANTXAREN ERDIAN ELKARTU AZALPENA EMATEKO

IRAK1

(115)IRAK1: (...) hemen berriro be elkartzen gara erdixen eta ya pasatzen gara atal nagusixa izango dana / apur bat azaldukotzau zein izango dan dinamika (14:57-15:35 irakaslea azalpena ematen azaltzen da bideoan) askotan nahiz eta abixau hasieratik eurek horretara doiaz / orduan lehen galdetu dozun bezela/ mezu horrek edo prestatutakuak die? Ba adibidez hau bai / dakitzulako zelan erantzun biotzuen / (...) askotan ikusi dutelako / ba bueno azalpena entzun aurretik ya esaten botzazu taldetan banatu bihar diela azalpena entzun barik doiez bilatzen euren taldiak / orduan ya ezdaue entzuten bez

(119-133) IRAK1: (...) berez haurrak die eta oindion haurrauak bihurtzen die espazio zabal batian/ lehen esan dogun bezela ba heziketa fisikua da arlo bat non mugimendu asko biada ez? eta orduan eurek mugimendu hori aprobetxatzen daue oindio umiauak izanaz / orduan ya zailtasunak berezkoak / zailtasun handixa da baina eske gero ya eurek oindio zailtasun haundixauak jartzen ditxuzte

I: Aha jarrera aldetik esaten dozu?

IRAK1: Hori da hori da ikusten dan bezela ba bueno bakoitza dao bere gauzetara/ zenbatek entzungo dauien azalpena hemendik? Ba bueno seguraski erdixa baino gutxio/ ikusten dugun bezela hemen neska batzuk eurenera / iñork ez dau 
IRAK1 (jarraitu)

kasorik itxen esandakuari / beste hau ba akrobaziak itxen hasi da bere kontu / bestea gora begira / eta orduen zenbatek entzun dauen? Ba ziur ziur ezdakit

I: Zalantzak dauzkazu hor

IRAK1: Baina baina

I: Eta zer da in dezakezuna? Edo nola ikusten duzu edo

IRAK1: Zaila

I: Zaila

IRAK1: Zaila/ zer hobetu neikien hortxe? esan bezela puntu bat atentziño hori indartzeko edo haunditzeko igual mezuaren bukaeran esan bikonauen taldiak in bitxustela / eta igual txarto in dotena da esaten taldiak aurretik / ze eurek ya hasten die euren taldiak sortzen / orduen ya azalpena ez jake inporta (...)

I: Ah: uhu

IRAK1: (19:08-19-25 Bideoan irakasleak esaten die ikasleei taldeak egiteko). Hor ikusten dan bezela aldez aurretik taldiak osatuta zazen

I: bai zeuden ya

IRAK1: Taldiak ya osatuta zaozen ze minutu bat emotetzau baina ya ikusten dan bezela bi segundutan taldia badaukie ez? orduan ya hitz egin daue azalpenan bitxartian (...) begirada bitxartez, ahoz edo biadana baina taldiak sortuta zazen ya

Aztergai duen ekintza, saioaren egitura tipikoaren baitan, atal nagusitzat jotzen du. Ohikoa eta kolektiboa den ekintzatzat dakar diskurtsora: «beti elkartzen gara», eta agentibitateari dagokionez, «gutik» tipifikatzen du ekintza. Badirudi «gu» horren atzean Heziketa Fisikoko kolektiboari erreferentzia egiten diola: «apur bat azaldukotzau». Bestalde, lehen aipatu bezala, biribilean erdian elkartzea azalpenak emateko ez da soilik saioaren hasieran egiten, saio guztian zehar erabiltzen da jardueraren dinamika azaltzeko.

Oraingoan, diskurtsora ekartzen du azalpen horietan askotan izan ohi duen zailtasuna: «dakitzulako zelan erantzun biotzuen / (...) askotan ikusi dutelako / ba bueno azalpena entzun aurretik ya esaten botzazu taldetan banatu bihar diela azalpena entzun barik doiez bilatzen euren taldiak / orduan ya ezdaue entzuten bez». Hau da, aurretik prestatutako eta eskarmentuaren ondorioz garatutako ezagutza azaleratzen du, askotan ikusi duelako hain zuzen ere. Horregatik, ikasleek azalpena entzun dezaten, aipatzen du ez dela egokia taldekatzeak nola egin behar diren ikasleei aurreratzea. Hau da, irakaslearen errekurtsoak azaltzen dira, barne-baldintzatzaileak, inguramenduaren aldarteak argitzen dituztenak. Gainera, kanpo-baldintzatzaileak ere ekartzen ditu diskurtsora, espazioari eta ikasleen izaerari dagozkionak: «berez haurrak die eta oindion haurrauak bihurtzen die espazio zabal batian/ lehen esan dogun bezela ba heziketa fisikua da arlo bat non mugimendu asko biada ez?». 
Hala eta guztiz ere, bideoa ikustean konturatzen da ikasleak bere azalpenari adi ez daudela : «ikusten dan bezela ba bueno bakoitza dao bere gauzetara/ zenbatek entzungo dauien azalpena hemendik? Ba bueno seguraski erdixa baino gutxio/ ikusten dugun bezela hemen neska batzuk eurenera / iñork ez dau kasorik itxen esandakuari / beste hau ba akrobaziak itxen hasi da bere kontu / bestea gora begira / eta orduen zenbatek entzun dauen? Ba ziur ziur ezdakit». Izan ere, ohikoa den egoera, aurretik azaldutako hori, ikusten ari da irakaslea bere jardunean. Hau da, preskribatutako lanaren eta lan errealaren arteko aldea ikusten da; izan ere, aurreikusitako ekintza hori ez du gauzatzerik izan.

Ikertzailearen galderaren ondorioz, hobekuntza proposamena egiten du: «atentziño hori indartzeko edo haunditzeko igual mezuaren bukaeran esan bikonauen taldiak in bitxustela / eta igual txarto in dotena da esaten taldiak aurretik / ze eurek ya hasten die euren taldiak sortzen / orduen ya azalpena ez jake inporta». Horrela, agentibitateari begira ikus daiteke hobekuntzaproposamena, kasu honetan, «ni» batetik egin duela: «hobetu neikien». Eta hobekuntza hori gainera, «igual» aditzondoarekin modalizatzen du. Autokonfrontazioak aukera eskaintzen du, bada, ekintza aztertzearekin batera, hobekuntza-proposamenak egiteko. Autokonfrontazioan zehar egilea jabetzen da egin duen ekintza hori posible ziren ekintzetako bat baino ez dela. Azken batean, Clotek (Clot et al., 2000:6) dioen moduan «C'est reconnaître le réel comme l'intégrale des bifurcations possibles de l'action». Modu horretan, irakasleak bere ekintza aztertzen duenean, arazoak identifika ditzake eta horiekiko hobekuntzak edota aldaketa posibleak aipatu. Proposamen horiek oraineko eta etorkizuneko balizko ekintzetan baliagarri gertatuko zaizkio, eta modu horretan, irakaslearen aldartea edo disposizioa aldatuz joango da.

\section{j) EKINTZA TIPIKOA: TALDEKATZEEN INGURUKO HAUSNARKETA ERAGIN}

\section{IRAK1}

(147-149)IRAK1: Hemen ba lehen galdetu bezela / bai bueno usten ditxut eurek itxia taldiak / eurek aukeratzen daue / nik ya aurreikusita nauken eurek inbidauiena dala euren laguna bilatu ez? Lehen hasieran aurrezagutzetan eta aipatu bezela garrantzitsua da euren kondiziñu fisikuak ikustea / batek aipatu dauen bezela / pisua / altuera edo eurek taldiak sortzerako orduan ezdie pentzetan jarri guzti horretan / eurek pentsatu dabien bakarra da nire laguna / orduen nik aurreikusita naukan hori pasatu behar zala ez? orduen eurei utzitziet bost minutu ekintza hori itxeko eta orduan suertau die zailtasunak/ indar falta alde batetik / pisu gehiegi bestetik eta bar/ eta gero beste bat aurreikusitxa zauana zan ekintza burutzerako orduen ezdie jarri pentzetan non kokatu laike pieza bakoitza ez? Orduan bakoitzak talde horretan eduki laikien rola ezdau ipini eta zuzenian joan die ekintzak itxen/ zer gertau da? ba ekintza askok ezdauiela urten / figura asko 
I: Planifikatu gabe edo:

IRAK1: Figura asko planifikatu gaberik zauan eta orduan ezdau urten / orduan ingo doguna da hausnarketa txiki bat eurekin konturatzeko taldiak itxerako orduan figura ezberdinak edo pieza edo rol ezberdinak hartzia / eta gero talde barruan be bakoitzak bere papera edo rola ematia /// Hor ikusi dan bezela bebai bideratu bestela juan laikie: edozein lekutara eta azkenian hori ez dozu bihar bezta / gurozuna da bideratzia eurek hausnarketa horretara edo puntu horretaz konturatzia /// Orduan hemen ikusi dan bezela (...) apur bat nahi nuelako eurek ohartzia guzti horretaz/ lagunak bai lagunak jolasteko orduan baina azkenean hau da taldeko lan bat eitxeko eta ikusibidaue talde lan batian rol desberdinak dazela eta hortaz konturatzia/ gero aukera emangotziet berriro be taldiak aldatzeko / eurek ez dabe aldatzen

Irakasleak figura akrobatikoak taldean gauzatzeko, lagun izateaz harago, ikasleen egoera fisikoa (altuera eta pisua) kontuan izatea funtsezkoa dela ikusarazi nahi die; azken batean, taldekatzeak egiteko kontuan hartu beharreko irizpideez hausnar dezaten eragin nahi du: «hausnarketa txiki bat eurekin konturatzeko taldiak itxerako orduan figura ezberdinak edo pieza edo rol ezberdinak hartzia / eta gero talde barruan be bakoitzak bere papera edo rola ematia».

Talde-lanaren izaeraz ari da irakaslea, taldean hartzen dituzten rolen inguruko hausnarketaz. Hausnarketa hori eginarazteko, ordea, metodo induktiboa darabil; hau da, ikasleak eurak jartzen ditu taldeak egiten inolako azalpenik eman gabe (eskarmentuak erakusten baitio taldekatzeko erabiltzen duen irizpide bakarretakoa «lagun» izaera dela) eta praktikatik abiatzen da horren gainean hausnartu eta ondorioak ateratzeko. Helburua, gainera, ez da irakasleak gertatu dena aztertzea, irakasleak ikasleen hausnarketa eragiten du eta ikasleen eginkizuna da hausnarketa horri esker, talde-lanaren izaeraz konturatzea: «apur bat nahi nuelako eurek ohartzia guzti horretaz / lagunak bai lagunak jolasteko orduan baina azkenean hau da taldeko lan bat eitxeko eta ikusibidaue talde lan batian rol desberdinak dazela eta hortaz konturatzia». Beraz, inguramenduaren aldarteak argitzen ditu. Eta agentibitateari dagokionez, balorazioa egiteko, «nitik» hitz egiten du: «gero aukera emangotziet berriro be taldiak aldatzeko / eurek ez dabe aldatzen».

Ekintza horietan ikus liteke ahozko hizkuntza, ahots goran egindako hausnarketak esaterako, bitarteko funtsezkoak direla Heziketa Fisikoko jarduerak modu arrakastatsuan egiteko. Beraz, hizkuntzaren eta heziketa fisikoaren arteko lotura ezinbestekoa da. 


\section{k) EKINTZA TIPIKOA: IKASLEEK AZPI-TALDETAN LANDU DUTENA IKUSI}

\section{IRAK1}

(202-209) IRAK1: klaro saio honen helburua / esan doguena ba bueno azkenian da ezagutzia / lehen kontaktu bat izango dana / bestien aurrian itxeko adibidez sekuentziako hirugarren saiuan etorriko da / bigarren saiuan egingo dauiena da ya oin ezagutu dituzten figura ezberdinak / ordun aukeratuko dituzte bertako figura ezberdinak eta ensaiauko dauiena da errepresentazio bat / eta azkeneko saio hortan beste guztion aurrian errepresentatu egingo dituzte/ hau berez zan ariketa bat edo figura bat eitxia / helburua da nik ikusteko benetan lantzen ibili diela ez? oso zaila dalako bakoitza leku batian egonda dana kontrolatu ahal izetia (...) honekin gure nauen ikustia talde guztiek

I: zure ebaluazioa edo

IRAK1: Hori da ebaluazio bat baina saio horrena ez akrosport guztiana eh: (...)

I: Eta danen artian ikusten daue bestiek egiten dutena eta igual auto-ebaluazio edo koebaluazio hori bideratzeko?

IRAK1: Ariketa honekin ez? ez ez berez bakoitza dao bere ariketan (...) helburu bakarra da ba bueno / nik itxeko ebaluazio jarrai bat / ez ixtia dana bukaerarako / eta hori ba bueno ikustia benetan saio honetan landu bizana landu dala / hori niri erakustia

I: Hor ebaluazioa zuk:/ eurek ebaluatzen dute hemen bere burua?

IRAK1: Ez ez ez daue itxen auto-ebaluazio propio bat eta: bueno gehienbat ba hori komentatzea zalantza hoiek ez?

Pasarte horietan ikusten da irakaslea ekintzaren helburua edo xedea autokonfrontazioan bertan argituz eta zehaztuz doala. Beraz, ekintza tipifikatu eta birtipifikatu egiten du. Hasiera batean ekintzaren xedea «ikasleek akrosporta ezagutzia» dela dio. Ezagutza hori, ordea, birformulatu egiten du eta helburua «ikasleek akrosportaren lehen kontaktua» izatea dela dio, gero besteen aurrean egiteko. Badu, ordea, epe luzeagorako helburua (hirugarren saiorako): figura bat hautatu, entseatu eta guztien aurrean errepresentazio bat egitn. Hondarrik hondarrean, ordea, birtipifikatzen du esanez «helburua da nik ikustea benetan lantzen ibili direla». Horrela, irakasleak ekintza tipifikatzen du ebaluazioa egiteko ekintza gisa, eta agentibitate markari dagokionez, ekintza «nitik» ekartzen du diskurtsora: «nik itxeko ebaluazio jarrai bat». Beraz, inguramenduaren aldarteak argitzen ditu, irakaslearen barne-baldintzatzailea da ikasleek egiten dutena behatzea eta ebaluatzea.

Horrez gain, ondorengo saioetan ikasleek figura akrobatikoen errepresentazioa prestatuko dutela dio. Errepresentazio hori honela tipifikatzen $\mathrm{du}$ : 
(209-214) I: (...) hemen gero errepresentazioari buruz ari zera:/ errepresentazioa da bakarrik egitea edo azaldu behar dute egin behar dutena edo nola:?

IRAK1: Suposatzen da errepresentaziño horrek eukiko dauela gioi bat

I: Gidoi bat

IRAK1: Hori da (...) hori ez da izango saio honen bezela / saio honetan dabitzena da ezagutzen figura ezberdinak / gero inbiko dabiena da lotura figuren artian eta aukeratu beharko ditxuzte figura batzuk erlaziñuak ditxuztenak zerbait errepresentatzeko ez? Orduan gero azaldu inbiko dabe ahoz zer errepresentau dauien/ ez da geratuko ba hori / figura batzuk itxiakin ez/ azaldu biko daue ba ezdakit / ehun zango bat piramide batera doiela edo bierdana / orduen ahoz be azaldu inbikodaue errepresentatutakoa eta hori ya guztien aurrien guztiek ikusiko daue: errepresentazio ezberdinak

I: Orduan azalpena bezela hor ere hizkuntzaren lanketarik ba al dago?

IRAK: Berez kontutan hartzekua ez / kontutan ez da hartuko baina berez landu ingo da hori baitxa

Pasarte horretan ikusten den bezala, irakasleak errepresentazio horrek gidoi bat izango duela dio eta ahoz azaldu beharko dutela zer errepresentatu behar duten. Deigarria da, ordea, diskurtsora ekartzen duen modua: «suposatzen da eukiko dauela» darabil. Ez da argi geratzen aurrez pentsatutako eta diseinatutako helburu bat den ala elkarrizketan bertan ari ote den helburu hori zehazten eta finkatzen. Garbi dago ez dela berariaz lantzen, eta hori ere esparru aproposa izan liteke hizkuntza eta arloaren artikulazioa gauzatzeko.

\subsubsection{Jarduera: paseak eta jaurtiketak lantzea}

1) EKINTZA TIPIKOA: AZALPENA EREDU GISA EMAN

\section{IRAK2}

(120-130)IRAK2: eta: hemen igual ez baina beste batzutan beti azaltzen dut lehenengo espazioa / non jolastu biou argi eta garbi eukitzeko eta gero helburua zein izengo dan eta gero ya helburu hori lortzeko ze arau dauzen zer nola pixkat ez? baina espazioa eta helburua lehenengo hori argi ta garbi eukitzeko eta gero nola lortu helburu hori

I: Helburu hori lortzeko zer egin behar duten

IRAK2: Hori bai / justo jolas hori igual ez da formatu horretakua baina

I: Ya // hor ere helburua azaltzen diezu ez? 
IRAK2 (jarraitu)

IRAK2: (34:50-36:19 irakaslearen azalpena eta irakasle-ikasle interakzioa jokoaren arauen azalpenean ikusten da bideoan) eta oin hori in daue borobila eta berriro azaldu dot mutiko batek ez dauelako ulertu / orduan berriz azaltzen dut ya jolastu behar dauen bezela pixkat I: Espazioan kokatuta ezta?

IRAK2: Hori da bai

I: Eredu gisa edo

IRAK2: Bai badaoz batzuk egon arte non eta zelan ez dabilela hain ondo ulertzen ez? orduan kokatu eta oin hau / ah bale!

I: Ze ikasleak desberdinak dira ez? ulertzen duten modua eta:

IRAK: Bai bai

Jarduera honetan irakasleak azalpenetan egin ohi duena ekartzen du diskurtsora; izan ere, bere azalpena ikustean, aurretik aipatutako azalpenarekin alderatzen du, atzeraeraginezko mugimenduak ikusten dira: «hemen igual ez baina beste batzutan beti azaltzen dut». Irakasleak jokoaren azalpena tipifikatzen du ondoren: «azaltzen dut lehenengo espazioa / non jolastu biou argi eta garbi eukitzeko eta gero helburua zein izengo dan eta gero ya helburu hori lortzeko ze arau dauzen zer nola pixkat ez? baina espazioa eta helburua lehenengo hori argi ta garbi eukitzeko eta gero nola lortu helburu hori». Pausoz pauso azaltzen du egin ohi duena eta azalpenean zeintzuk diren kontuan hartzekoak, izan ere, ikasleek ezagutzen ez duten ekintza baten aurrean daudela dio. Horrez gain, ikasle guztiek ulertzeko moduan azaltzen saiatzen da eta kontuan hartzen du ikasle batek ez duela ulertu. Horren ondorioz, irakaslearen eta ikertzailearen elkarrekintza sortzen da, eta ikertzailearen galderaren ondoren izendatzen du «eredu gisa» ekintza. Hau da, jolastu behar duten espazioan kokatuta azaltzearen beharra aipatzen da.

Hortaz, inguramenduaren aldarteak ekartzen ditu diskurtsora irakasleak. Azalpena egitean kontuan hartzen dituen alderdiak barne-baldintzatzaileak argitzen ditu. Baina horrez gain, espazioaren baldintzak edo kanpo-baldintzatzaileak azaltzen ditu azalpenak espazioan kokatuta egitearen garrantzia azaltzean.

Agentibitateari dagokionez, «nitik» hitz egiten du irakasleak bere azalpenari buruz ari denean: «azaltzen dut». Hala ere, jolasari edo ekintzari buruz ari denean, «non jolastu biou», «gutik» azaltzen du ekintza kolektibo gisa. Kasu honetan, badirudi «gu» horren atzean irakasle- eta ikasle-taldea dagoela. 


\subsubsection{Jarduera: partidu zabala jokatzea}

\section{m) EKINTZA TIPIKOA: DENON PARTE-HARTZEA ZIURTATZEKO PARTIDUA ANTOLATU}

IRAK2

(143-144)I: Antolaketa hori? (...) Hor zer bideratzen duzu?

IRAK2: Ba antolatzen dugu partidu zabal-zabal bat kanasta askokin eta baloi askokin eta orduan bideratzen dot danon parte hartzea / taldeka hobeto antolatzia / hau da / kasnasta bat zaindu beharrian bi zaindu behar ditxut orduan taldea ondo antolatu behar da / elkarrizketa / emaitzari garrantzia kentzia ez dielako gai kontatzeko zenbat kanasta sartu dien guztira eta gero eurak ondorio guzti hauek ateratzen ditxuzte ez? (40:08-40:17 irakasleak bideoa aurreratzen du) hemen jartzen ditxut pentsatzen pixkat / zergatik ez? ba hori / zer desberdintasun dau partidu bat holan jolastu eta partidu normal baten artean? Eta eurek nik esandako guztia segitxuan ateratzen daue eta konturatzen dia segitxuan eta gehixenok eskertu itxen daue askoz dibertigoagoa dalako eta aukera gehixao ematen dotzielako baloia ikutzeko edo parte hartzeko (40:45-40:59 ikasleen erantzunak entzuten bideoan) bai dao esaten bi edo hiru bakarrik ezin dabiela ezer ein / pixkat talde guztia beharrezkoa dala ondo jolasteko/ beraiek segitxuan ateratzen ditxuste ondorioak $[\ldots]$

Pasarte horietan ikusten da ikertzailearen galdera baten ondorioz, partiduaren antolaketa zabalaren tipifikazioan parte-hartzearen garrantzia azpimarratzen duela irakasleak: «antolatzen dugu partidu zabal-zabal bat kanasta askokin eta baloi askokin eta orduan bideratzen dot danon parte hartzea». Horrez gain, ikasleen hitzak ekartzen ditu diskurtsora hori justifikatzeko; ez du, bada, egiten dutena aztertzeko bere baitatik bakarrik hitz egiten, polifonia edo ahots ugari dakartza diskurtsora. Batetik, irakasleak berak saioan bertan egindako galderak («zergatik ez? ba hori / zer desberdintasun dau partidu bat holan jolastu eta partidu normal baten artean?») dakartza; bestetik, ikasleen ahotsa («askoz dibertigoagoa dalako»). Horrez gain, irakasleak saioa aztertzerakoan, autokonfrontazioan ematen dituen arrazoiak («eta aukera gehixao ematen dotzielako baloia ikutzeko edo parte hartzeko») ere hor daude. Batzuetan, irakasleak «ni» batetik hitz egiten du ( «hemen jartzen ditxut pentsatzen pixkat»); beste batzuetan, «gu» batetik ( $\ll \mathrm{Ba}$ antolatzen dugu partidu zabal-zabal bat»), baina «gu» hori ere polifonikoa da, ikasle-irakasle multzoa ordezka dezake baita irakasle-kolektiboa ere.

Aipagarri da bai IRAK1ek, bai IRAK2k beren ekintzen artean ikasleak egin dutenaz pentsatzen jartzea edo hausnarketa eragitea oso presente dagoela eta ez direla egite soilera mugatzen. Hausnartzearen ekintza 
hori, gainera, saioaren baitan atal ezberdinetan agertzen da, baita amaieraamaieran ere.

\subsubsection{Jarduera: saioaren hausnarketa eginaraztea}

n) EKINTZA TIPIKOA: IKASLEEN INPRESIOA JASO

\section{IRAK2}

(144)IRAK2: (...) eta hemen partiduaren hausnarketa egin eta gero pixkat jartzen ditut hausnartzen bebai saio guztiari buruz pixkat nik be jasotzeko beraien inpresiua ez? ze moduz saiua? Dibertigarria? ez dibertigarria? Hau aspergarria / hau ondo / hau txarto / hau gustau jat / hau ez jat gustau/ pixkat horri buruz hitz egiten deu beste hiru lau minutu (...)

Pasarte honetan IRAK2k saioaren hausnarketa ekartzen du diskurtsora: «jartzen ditut hausnartzen bebai saio guztiari buruz». Aipagarria da «ditut» agentibitate-marka erabiltzen duela jarduera diskurtsora ekartzeko; kasu honetan, beraz, «ni» batetik hitz egiten du jarduera indibidual gisa. Gainera, kasu honetan IRAK1ek ez du saioari buruzko hausnarketa-jarduera diskurtsora ekartzen. Jarduera tipiko horren baitan, IRAK2k ikasleen inpresioa jasotzea ekintza tipifikatzen du; hau da, saioari buruz galderak egitea: saioa zer iruditu zaien, dibertigarria izan den, aspergarria izan den eta saioan zer gustatu zaien eta zer ez. Beraz, ikasleen inpresioa jasotzeko barne-baldintzatzailea azaleratzen da, inguramenduaren aldarteak argitzen dituena.

Saioaren bukaeran IRAK2k egiten duen saioaren hausnarketan, ikasleen inpresioak jakiteko ekintza tipikoan, beste behin ere, eztabaida ez-formala sortzeko aukera argia dago. Ikastetxe horretan, heziketa fisikoaren eta hizkuntzaren artikulaziorako errepikatzen den generoa da. 


\subsubsection{Jarduera: lasaitasunera bueltatzeko joko/jolas bat egitea}

o) EKINTZA TIPIKOA:

ATZAMARRETAKO GIHARRAK LANDU p) EKINTZA TIPIKOA: JAURTIKETA

LIBRE TXAPELKETA ANTOLATU

\begin{tabular}{|c|c|}
\hline IRAK1 & IRAK2 \\
\hline $\begin{array}{l}\text { (195-197)IRAK1:[...]ya bueno la- } \\
\text { saitasunera bueltako ba jolastxo bat ho- } \\
\text { nen ostian ya dutxara joateko / hau da / } \\
\text { ba bueno lasaitasunera itzulerako bebai } \\
\text { ba bueno erabili dou giharrekin (...)/ } \\
\text { giharren gaixa landu genunian landu ge- } \\
\text { nuen ariketatxo bat azkenian ba atza- } \\
\text { marretako giharrak be eskuko giharrak } \\
\text { lantzeko } \\
\text { I: Honek ere akroport akrosporte- } \\
\text { kin: } \\
\text { IRAK: Bai giharrakin lotura bat } \\
\text { iñaz bion artian eta honekin ya buka- } \\
\text { tzen daue }\end{array}$ & $\begin{array}{l}\text { (144)IRAK2:[...] eta gero amai- } \\
\text { tzeko jaurtiketa libreen txapelketa bat } \\
\text { itxen dou oso gustokua beraientzat/ } \\
\text { beste ariketa batzuk bebai badaoz lasai- } \\
\text { tzeko baina: hori ez? baloiarekin trebe- } \\
\text { ziak edo bueltak emon orkatilaren ingu- } \\
\text { ruan / buruaren inguruan / baina biharko } \\
\text { nitxuen ba hogeita zazpi baloi eta: } \\
\text { I: Ya klaro klaro } \\
\text { IRAK2: Eta ez asko die asko die } \\
\text { hamazortzi hamabost igual bai baina } \\
\text { hogeita zazpi ba ba ez / eta oso gustoko } \\
\text { daukie eta gainera aukera emuten dau / } \\
\text { tiro libre bat edozein momentuan edo- } \\
\text { zeinek sartu leike eta batzutan ba kasu } \\
\text { honetan justu Iliak uste dot sartu zauela } \\
\text { eta berarentzako izan zan bueno aldage- } \\
\text { letara heldu zan eta poz pozik ez? }\end{array}$ \\
\hline
\end{tabular}

Azken jarduera hau ere egitura tipikoaren baitan kokatzen da, IRAK1ek dioen moduan, «lasaitasunera bueltako» jolas bat, edo IRAK2kdioen bezala, «lasaitzeko». Baina, irakasle bakoitzak lasaitasunera bueltatzeko joko desberdinak egiten ditu. Bertan gauzatzen den ekintza lasaitasunera bueltatzeko jolas gisa tipifikatzen du IRA1ek, ariketa bat atzamarretako giharrak ere lantzeko. Izan ere, lotura egiten du aurretik landutako gai batekin («giharren gaixa landu genunian»); barne-baldintzatzaile horrekin justifikatzen du ekintza hau planteatzea.

IRAK2k diskurtsora ekartzen duen ekintza jaurtiketa libreen txapelketa da eta aipatzen du dela «oso gustukoa beraientzat». Helburu horretarako, beste balizko ekintza tipiko batzuk ekartzen ditu diskurtsora: «beste ariketa batzuk bebai badaoz lasaitzeko». Kasu honetan, «badaoz» aditz inpertsonala erabiltzen du hobekuntza proposatzeko. Horrela, zer egin zitekeen ere aipatzen du : baloiarekin trebeziak edo baloia gorputzetik mugitzea, baina ekintza hori kanpo-baldintzatzaileek baldintzatzen dute: «baina biharko nitxuen ba hogeita zazpi baloi eta:». Hau da, material falta kanpo- baldintzatzailearen baldintza ekartzen du diskurtsora. Deigarria da Ira2k oraingoan ere atzeraeraginezko mugimendua egiten duela egindako lana justifikatzeko. 


\section{ONDORIOAK}

Ondorioak azaltzeko, ikerketa honen helburuei erreparatuko zaie, horiek baitira ikerketaren abiapuntu. Lehen helburua izan da aztertzea eta deskribatzea Heziketa Fisikoko bi irakasleek diskurtsora ekartzen dituzten jarduera eta ekintza tipikoak (Schütz, 2007). Azterketa horretarako, autokonfrontazio-metodoa erabili da; metodo horri esker, irakasleek hainbat jarduera eta ekintza azaleratu, deskribatu eta sakondu dituzte. Beraz, esan liteke irakasleek egiten dituzten ekintzen zentzua eta arrazoiak ezagutzeko, metodo erabat pertinentea dela . Horren baitan, aztertu da irakasleek jarduera eta ekintzak nola tipifikatu eta ezaugarritzen dituzten (batzuetan birtipifikatu ere bai). Halere, nahiz eta ikerketa honen berariazko helburua ez izan, autokonfrontazio-metodoan sakontze aldera, interesgarria litzateke aztertzea ikertzailearen galderek zer nolako eragina izan duten; izan ere, zenbaitetan, tipifikazio batzuk sakontzeko baliagarriak izan direlako ustea dugu.

Autokonfrontazioaren analisian argi geratu da bi irakasleek «ohikoa, beti, askotan» bezalako aditzondoak maiz erabiltzen dituztela jarduera eta ekintza tipikoak azaleratzeko, eta hori ere bada aztergai dugun ikastetxeko heziketa fisikoko tipikalitatearen aztarna. Hala ere, zail da zehazten irakasleek diskurtsora ekartzen dituzten jardueretatik edo ekintzetatik zeintzuk diren kolektiboak. Azterketa horretarako, irakasleek beren diskurtsoan azaldutako ardura enuntziatiboa onartzeko mekanismoak, agentibitate-markak edo aztarnak aztertzea funtsezkoa gertatu da. Beraz, ikusi da irakasle horiek jarduera eta ekintza asko kolektibo bezala ekartzen dituztela diskurtsora; batetik, «gutik» hitz eginez («doguena, emoten tzau, bideratzen dogu, saiatzen gara, ditxugu»...) eta bestetik, modu inpertsonala erabiliz («garrantzia haundixa ematen zauena da», «garrantzitsua da», edo «beste ariketa batzuk bebai badaoz lasaitzeko»). Ildo honetatik, interesgarria litzateke agentibitate-marka horien arrazoi zehatza ezagutzea. Izan ere, «gu» horren atzean hainbat aukera egon daitezke eta ezin izan da kasu guztietan zehaztu horren atzean irakasle- kolektiboa, Heziketa Fisikoko irakasle-kolektiboa, irakasle-talde zehatz bat, edo irakasle-ikasle taldea ote dagoen.

Horrez gain, irakasleek une askotan egin dituzte ekintzari buruzko intentzioak, desioak, jabetzak, kezkak eta balorazioak autokonfrontazioan zehar, eta maiz ekarri dituzte diskurtsora barne- eta kanpo-baldintzatzaileak. Hau da, irakaslearen eduki mental eta emozionalen bitartez azaleratu dira jarduera- inguramenduaren aldarteak. Alderdi honetan, aipagarria da gehien azaldu dituzten aldarteak barne-baldintzatzaileak izan direla. Baldintzatzaile edo intentzio horietatik, preskribatutako lana eta lan errealaren aldea azaldu da, batez ere IRAK1en kasuan. IRAK2ren kasuan ordea, atzeraeraginezko mugimenduak azaldu dira batik bat. Hau da, irakasleak aurretik egindako ekintza diskurtsora ekarri du ikusten ari zen ekintza azaltzeko edo justifikatzeko. 
Aztertutako testuinguru horretan, erregulartasun-modura errepikatzen diren ekintza-patroiak ere identifikatu dira. Izan ere, espazio- eta denboraantolaketan erregulartasunak eta saioaren sekuentzia-tipoa antzeman da; hau da, saioaren honako egitura tipikoa azaleratu da: saioa kokatzea $>$ berotzea $>$ atal nagusia $>$ lasaitasunera bueltatzea. Saioaren egiturak irizpide anatomiko-fisiologikoa azaleratzen duen arren (berotzea, atal nagusia eta lasaitasunera bueltatzea), irizpide pedagogiko-didaktikorako aldaketa antzematen da. Izan ere, aztertutako kasuetan, saioaren egitura horretara gehitu diren jarduerak dira batetik, aurrezagutzak azaleratzea eta bestetik, saioaren hausnarketa eginaraztea .

Horrez gain, Gal-Petitfaux eta Sauryren (2002) lanean bezala, zuzendu nahi duten jokabide baten aurrean erregulazio-ekintza tipikoak azaleratzen dira gurean ere. Batetik, analisian ikusi bezala, IRAK1ek «i» ekintza tipikoan harrapaketa joko-jolasean mezu zuzenak ematen dituela dio. Erregulazio mota hori aditu horiek «flash» izendatzen duten ekintzaren parekoa da: bere intentzioa da ikasleengana gerturatzea eta jokabide kolektiboak zuzentzea. Gure aztergaian, «suivi» edo jarraipena ere egiten die ikasleei memento horretan irakasleek. Bestetik, bi irakasleengan errepikatzen den ekintza tipikoa azaleratzen da: ekintza geratu edo eten, ikasleak elkartu eta biribilean jartzea hausnarketa bat egiteko. Erregulazio-ekintza tipiko horrek «arrêt» edo gelditzea ekintzarekin bat egiten du. Nahiz eta aztergai den kasuan indibiduala izan beharrean kolektiboa izan, ekintza gelditu eta arrazoiak argitzeko hausnarketa-espazioa sustatzen dute irakasleek. Hau da, irakasleek erregulazio- ekintza tipiko honi jarraitzen diote: lehenbizi, jokoaren edo jolasaren jarraipena egiten dute, eta arazo edo hobetzeko alderdi bat ikustean, jokoa edo jolasa gelditu eta biribilean elkartzeko deitzen dituzte ikasleak. Horrela, irakasleak zuzendu nahi duen jokabidearen arrazoiak argitzeko hausnarketa bideratzen du, jokoarekin edo jolasarekin ondoren jarraitzeko.

Horren harira, Gal-Petitfaux eta Vorsen (2008) lanean ondorioztatzen den bezala, irakaslearen eta ikaslearen arteko sozializazio-prozesu interaktiboetan sortzen da esanahien eraikuntza, eta eraikuntza prozesu horretan, negoziazioak ere oinarrizko papera du. Horrez gain, ikaslearen eta irakaslearen arteko prozesu interaktiboetan esanahiak elkarrekin eraikitzea sustatu nahi da eta eraikuntza-prozesu horretan negoziazioek duten garrantzia nabarmena da. Bi irakasleek instrukzioak emateko zein esanahiak eraikitzeko elkarrizketak sortzen dituzte, hausnartzea, pentsaraztea eta ideiak azalaraztea moduko ekintzak ekartzen baitituzte diskurtsora.

Esanahien eraikuntza bideratzeko, elkarrekintzarekin lotuta, ikerketaren hirugarren helburua izan da jarduera eta ekintza tipiko horietan heziketa fisikoaren eta hizkuntzaren arteko artikulazioa baimentzen duten ekintzak aztertzea. Horrela, jakintza-arloaren eta hizkuntzaren arteko artikulazioaren aztarnak atzeman dira.

Horrenbestez, azpimarratu nahiko genuke Heziketa Fisikoa esparru aproposa izan daitekeela Hizkuntzaren Didaktikarekin loturiko ekintzak 
gauzatzeko eta hizkuntza- komunikaziorako gaitasuna garatzeko (Larraz, 2008; Vaca Escribano, 2008; LLeixà, 2007). Gainera, ikusi dugu ahozko hizkuntza garatzeko ere testuinguru naturala eta esanguratsua gerta daitekeela . Izan ere, IRAK1ek, esaterako, eztabaida ez-formala, instrukzioak (jolas-arauak), gidoia eta gidoi horren errepresentazioa azaltzeko testu- generoak lantzea baimentzen dituzten ekintzak aipatzen ditu. IRAK2ren egiteko moduetan ere, eztabaida ez-formala, instrukzioak (jolas-arauak) eta bizipenaren azalpena edo kontaketa lantzeko ekintzak gehiegi behartu gabe artikula litezke.

Hala ere, ez da ikusi ekintza horietan hizkuntza objektu gisa berariaz lantzeko intentziorik, badirudi gaur egun ez dagoela Heziketa Fisikoko irakasle hauen lehentasunen artean. Heziketa Fisikoko jardueretan hizkuntzaren alderdiari erreparatzeak (hiztegi espezifikoa, ahots goran egindako hausnarketak, errepresentazioetako aurkezpenak, joko-jolasen instrukzioak...) eta ikuspegi sozio-diskurtsibotik berba elkarrekintzak sustatu (Dolz \& Schneuwly, 1997; Plazaola, 2010) eta modu artikuluatuan lantzeak heziketa fisikoan bertan ere arrakasta handiagoz aritzea ekar lezake eta aktibismorako eta errekreazionismorako joera hori gainditu. Lagundu dezake pentsamenduaren, elkarrizketaren eta kontzientzia hartzearen galerari aurre egiten (Barbero Gonzalez, 2005). Hori guztia bidera daiteke motibagarria den hizkuntza-jarduera sozial batean; izan ere, Heziketa Fisikoak duen izaera motibagarriaz gain, talde-lana eta adierazpena oinarri duten ekintzak ugari dira, non ikasleen arteko eta irakasle-ikasleen arteko hizkuntza elkarrekintza beharrezkoa den.

The aim of this article is to examine the activity of two physical education teachers and how they perform it. So it has emphasized three specific objectives: first, to analyse typical actions carried out by the two teachers of physical education and also to emerge the regularities that exist in them. Second, to analyse how these teachers typify or characterize those actions. And thirdly, to analyse if some articulation between physical education and the language takes place in these activities and, if it is so, it is also our duty to analyse how they are made. In order to do that, it will consider the self-confrontation interviews done by two physical education teachers from an Ikastola in Gipuzkoa. All this is part of the analysis of action and the continuous training research. Its main goal is to understand the actions of 
physical education teachers, so new training resources can be created. The first results show that in the activities of the teachers of physical education there are regularities and privileged areas to articulate with the language, but they are not intentionally worked on.

Keywords: analysis of action, self-confrontation, typical actions, typification.

El objetivo de este artículo es analizar la actividad de dos profesores de educación física y su modo de hacer. Se han subrayado tres objetivos concretos: primero, analizar qué acciones típicas realizan los dos profesores de educación física y emerger las regularidades que existen. Segundo, analizar cómo tipifican o caracterizan los profesores esas acciones. $Y$ en tercer lugar, analizar si en esas actividades se realiza articulación alguna entre la educación física y la lengua y, si así fuera, también es objetivo de la investigación examinar cómo se realiza. Para eso, se analizan 2 sesiones de autoconfrontación sobre sendas sesiones de educación física llevadas a cabo por 2 profesores de una ikastola de Guipúzcoa. La investigación se ubica en el ámbito del análisis de la actividad y la formación continua. El interés de esta investigación se sustenta en entender el modo de actuar de los profesores de educación física para así poder crear nuevos entornos de formación. Los primeros resultados demuestran que en las actividades que realizan estos profesores de educación física existen regularidades y ámbitos privilegiados para la articulación con la lengua, pero que no se trabajan intencionadamente.

Palabras clave: análisis de la actividad, autoconfrontación, acciones típicas, tipificaciones.

Cet article a pour objet de mener une analyse de l'activité et du mode de procédure de deux enseignants d'éducation physique. Nous avons pour cela, choisi de mettre particulièrement en avant les trois objectifs suivants: le premier visant à analyser la nature des actions typiques menées par les deux enseignants d'éducation physique et mettre en lumière les règles mises en pratique dans ces actions typiques. Le second concernant l'étude de la manière employée par ces enseignants pour caractériser ces actions. Et le troisième qui porte sur le fait de vérifier que l'articulation entre l'éducation physique et la langue s'opère, et, si c'est le cas, de voir de quelle manière celle-ci se concrétise. Pour cela nous avons procédé à l'étude des discussions d'auto confrontation sur une séance menée par chacun des 2 enseignants d'éducation physique d'une ikastola du Gipuzkoa. Tout cela se faisant dans le cadre d'une analyse de l'activité et dans le champ d'étude de la formation continue. L'intérêt de cette étude porte sur la compréhension de l'action de ces enseignants d'éducation physique, 
dans le but de créer de nouveaux milieux de préparation. Les premiers résultats démontrent une régularité dans l'activité des enseignant(e) $s$ d'éducation physique et l'existence d'espaces privilégiés permettant une articulation avec la langue, mais qui ne sont pas intentionnellement travaillées.

Mots-clé: analyse de l'action, auto confrontation, actions typiques, caractérisations.

\section{ERREFERENTZIAK}

Barbero González, A. (2005). La lección de Educación Física en la formación del profesorado. Aproximación a las expectativas y resistencias del alumnado a partir de dos modelos significativamente diferentes. In: Vaca, M.J., Sagüillo, M., Barbero, J.I., García, A.J., Aguado, A.M., Martínez, L., Bores, N.J. (coord.) (2005). La lección de Educación Física en el Tratamiento Pedagógico de lo Corporal, (102-118). Barcelona: INDE

Béguin, P., Clot, Y. (2004). L'action située dans le développement de l'activité, @ ctivités, 1 (2), 27-49. Hemendik jasoa: http://www.activites.org/v1n2/beguin. fr.pdf

Bores Calle, N. (coord.), Vaca Escribano, M., Sagüillo Rodriguez, M., Barbero González, J. I., García Monge, A. J., Miguel Aguado, A., \& Martínez Álvarez, L. (2005). La lección de Educación Física en el Tratamiento Pedagógico de lo Corporal. Barcelona: INDE.

Bronckart, J.P. (2007). La enseñanza de la lengua: para una construcción de las capacidades textuales. In: Bronckart, J.P. (2007). Desarrollo del lenguaje y didáctica de las lenguas, (133-146). Madrid: Miño y Dávila Editores.

Cefaï, D. (1994). Type, typicalité, typification. La perspective phénomenologique. In: Fradlin, B., Quéré, L. \& Widmer, J. (dir.). L'enquète sur les catégories. De Durkheim à Sacks, (105-128). Paris: Editions de l'EHESS.

Clot, Y., Faïta, D., Fernandez, G., Scheller, L. (2000). Entretiens en autoconfrontation croisée : une méthode en clinique de l'activité. Pistes, 1 (2), 1-7. Hemendik Jasoa: http://pistes.revues.org/3833

Coelho, E.,(2004). Adding English: A guide to teaching in multilingual classrooms. Pippin Publishing Corporation.

Del Valle Díaz, M. S., De la Vega Marcos, R. (2007). El papel reservado al profesor de Educación Física: organizador de la interacción del alumno con el conocimiento a través del juego. Lecturas: Educación física y deportes, (105), 12.

Dolz-Mestre, J., Schneuwly, B. (1997). Géneros y progresión en expresión oral y escrita. Elementos de reflexión a partir de una experiencia realizada en la Suiza francófona. Textos de didáctica de la lengua y de la literatura, 11, 7798.

Esteve, O. (2009). La interacción, un proceso que implica conversar. Cuadernos de pedagogía, (391), 56-59. 
Esteve, O., Alsina, A. (2010). Hacia el desarrollo de la competencia profesional del profesorado. In: Esteve, O., Melief, K. \& Alsina, A. (coord.). Creando mi profesión, (7-18). Barcelona: Octaedro.

Gal-Petitfaux, N., Durand, M. (2001). L'enseignement de l'éducation physique comme «action située»: propositions pour une approche d'anthropologie cognitive. STAPS, 55, 79-100. Hemendik jasoa: http://spiralconnect.univ-lyon1.fr/ spiral-files/download?mode $=$ inline $\&$ data $=2147012$

Gal-Petitfaux, N., Saury, J. (2002). Analyse de l'agir professionnel en éducation physique et en sport dans une perspective d'anthropologie cognitive. Revue Française de Pédagogie, 138, 51-61. Hemendik jasoa: http://www.persee.fr/ web/revues/home/prescript/article/rfp_0556-7807_2002_num_138_1_2863

Gal-Petitfaux, N., Vors, O. (2008). Socialiser et transmettre des savoirs en classe d'éducation physique: une synergie possible au prix d'une autorité pédagogique conciliante. Éducation et Francophonie, 36 (2), 118-139. Hemendik jasoa: http://quebec.synergiescanada.org/revue/ef/2008/v36/n2/029483ar.pdf

García Monge, A.(2005). La lección de juego motor reglado. In: Vaca, M.J., Sagüillo, M., Barbero, J. I., García, A. J., Aguado, A. M., Martínez, L., Bores, N. J. (coord.)(2005). La lección de Educación Física en el Tratamiento Pedagógico de lo Corporal, (121-148). Barcelona: INDE.

Larraz, A. (2008). Valores y dominios de acción motriz en la programación de educación física para la educación primaria. En Estrada, N. \& Rovira, G. (coord.). XI Seminario Internacional de Praxiología Motriz. Educación Física y Valores, Febrero 22-23, 1-30. Zaragoza: Prensas Universitarias de Zaragoza. Hemendik jasoa: http://efypaf.unizar.es/rec/PONENCIAALFREDO LARRAZpraxiologia.pdf

Leontiev, A. (1984). El problema de la actividad en psicología. In: Leontiev, A. (1984). Actividad, conciencia y personalidad. (60-97). Mexico: Editorial Cartago.

López Pastor, V.M (coord.). García, J.M., García- Peñuela, A., Gonzalez, M., López, E., Monjas, R., Pérez, D., Archilla, M. (2005). ¿Cuándo tenemos poco prestigio? Mirando la viga en el ojo propio. Causas internas y reflexiones del estatus de educación física. Retos. Nuevas tendencias en Educación Física, Deporte y Recreación 8,11-18.

LLeixà. T. (2007). Educación física y competencias básicas. Contribución del área a la adquisición de las competencias básicas del currículo. Tándem. Didáctica de la Educación Física, 23, 31-37.

Montmolin, M. (1986). L'intelligence de la tâche. Eléments d'ergonomie cognitive. Berne: Peter Lang.

Ozaeta, A. (2013). Hizkuntza irakasleen prestakuntzarako eta prestakuntzaren ikerketarako proposamen bat. Ikastaria, 19, 69-95. Hemendik Jasoa: http:// www.euskomedia.org/PDFAnlt/ikas/19/19069095.pdf

Parlebas, P. (2008). Juegos, deporte y sociedades. Léxico de praxeología motriz (Vol. 36). Barcelona: Editorial Paidotribo.

Plazaola Giger I., Friedrich J. (2005). Comment l'agent met-il son action en mots? Analyse d'entretiens auprès d'enseignants. In: L. Filliettaz et J.-P. Bronckart (Ed.). L'analyse des actions et des discours en situation de travail. Concepts, méthodes et applications, (241-261). Louvain-La-Neuve: Peeters. 
Plazaola Giger, I. (2006). Didáctica y análisis de la actividad en el trabajo:¿ qué aportan a la investigación en el aula?. In: Diálogo e investigación en las aulas: investigaciones en didáctica de la lengua (205-220). Barcelona: Graó.

Plazaola Giger I. (2007a). La leçon racontée par l'enseignant: analyse de l'agir textualisé. In: I. Plazaola Giger et K. Stroumza (Ed.). Paroles de praticiens et description de l'activité. Outils méthodologiques pour la formation, (37-62). Bruxelles: De Boeck.

Plazaola Giger, I. (2007b). Las interacciones en clase de segundas lenguas como contenido de formación del profesorado, Cultura y Educación,19 (2), 183-196.

Plazaola Giger, I. (2010). Irakaslearen berbaldia ikaslearen ikaskuntzen eraikuntzan: hizkuntzaren eta ikasgaiaren uztartzea, HIK HASI, 25. Monografikoa, 41-50.

Plazaola Giger, I., Ruiz Bikandi, U. (2012). La formación del profesorado para la enseñanza de lenguas: un dispositivo innovador y una red de investigación. In: Ruiz Bikandi, U. \& Plazaola, I. (ed.). El aula como ámbito de investigación sobre la enseñanza y aprendizaje de la lengua, (201-214). Donostia: EHU. Hemendik jasoa: http://www.google.es/url?sa=t\&rct=j\&q=\&esrc=s\&source $=$ web $\& \mathrm{~cd}=1 \& \mathrm{cad}=\mathrm{rja} \&$ uact $=8 \& \mathrm{ved}=0 \mathrm{CCEQFjAA} \& u r l=\mathrm{http} \% 3 \mathrm{~A} \% 2 \mathrm{~F} \% 2 \mathrm{~F}$ www.ehu.es\%2Fargitalpenak\%2Fimages $\% 2$ Fstories\%2Flibros_gratuitos_en_ pdf\%2FCiencias_Sociales\%2FV_Seminario.pdf\&ei=JHAJVL_1I8nfaoe2gv AC\&usg=AFQjCNGEq-pl-RI2pBbVer6JU0101Fw20g\&sig2=j5aduCxvWzf4ACC1RavGw

Pradas, R. (2010). El estudio del pensamiento del profesorado sobre la toma de decisiones interactivas: análisis de un caso en educación física escolar. Cultura y Educación, 22 (1), 21-36.

Pradas, R., López Ros, V. (2010). Acción Docente y pensamiento del profesorado. Análisis de un caso desde la perspectiva de la 'acción situada. Docencia, innovación e investigación en educación física, (296-317). Barcelona: INDE.

Ria, L. Sève, C., Saury, J., Thereau, J. \& Durand, M. (2003). Beginning teachers' situated emotions: a study of first classroom experiences. Journal of Education for Teaching, 3 (29), 219-235. Hemendik jasoa: http://halshs. archivesouvertes.fr/docs/00/80/39/89/PDF/beginning_techers_situateds_ emotions_ria_seve_theureau_saury_durand.pdf

Richir, M. (1988). Relire la « Krisis » de Husserl, Esprit, 140-141, 129-151.

Saury, J., Ria, L., Sève, C., Gal-Petitfaux, N. (2006). Action ou cognition située. Enjeux scientifiques et intérêts pour l'enseignement en EPS. Éducation Physique et Sportive, 321, 5-11.

Sainz Osinaga, M. (koord.), Azpeitia, A., Garro, E. \& Sagasta, P. (2011). Nola artikulatu jakintza-arloa eta hizkuntza? Zenbait lanabes eskolan erabiltzeko. Andoain: Euskararen Gizarte Erakundeen Kontseilua.

Schütz, A. (1972). La formulación de nuestro problema: los conceptos metodológicos de Max Weber. In: Schütz, A. (1972). Fenomenologia del mundo social: introducción a la sociología comprensiva, (33-74). Barcelona: Paidós.

Schütz, A. (2007). Essais sur le monde ordinaire. Preface et traduction deThierry Blin. Paris:Le félin.

Theureau, J. (1992). Le cours d'action: analyse sémiologique. Essai d'une anthropologie cognitive située. Berne: Peter Lang. 
Theureau, J. (2005). Les méthodes de construction de données du programme de recherche sur les cours d'action et leur articulation collective, et ... la didactique des activités physiques \& sportives ?. Impulsion, 4, 281-301. Hemendik jasoa: http://www.coursdaction.fr/05-Articles/2005-JT-R36.pdf

Vaca Escribano, M. (2008). Contribución de la educación física escolar a las competencias básicas señaladas en la LOE para la educación primaria. Tándem. Didáctica de la Educación Física, 26, 52-61. 